\title{
IAP-Mediated Protein Ubiquitination in Regulating Cell Signaling
}

\author{
Baptiste Dumétier $\left.{ }^{1,2}{ }^{(}\right)$, Aymeric Zadoroznyj ${ }^{1,2}$ and Laurence Dubrez ${ }^{1,2, *(\mathbb{C}}$ \\ 1 Institut National de la Santé et de la Recherche Médicale (Inserm), LNC UMR1231, 21000 Dijon, France; \\ Baptiste.Dumetier@u-bourgogne.fr (B.D.); Aymeric.Zadoroznyj@u-bourgogne.fr (A.Z.) \\ 2 Université de Bourgogne Franche-Comté, LNC UMR1231, 21000 Dijon, France \\ * Correspondence: ldubrez@u-bourgogne.fr
}

Received: 6 April 2020; Accepted: 28 April 2020; Published: 30 April 2020

\begin{abstract}
Over the last decade, the E3-ubiquitine ligases from IAP (Inhibitor of Apoptosis) family have emerged as potent regulators of immune response. In immune cells, they control signaling pathways driving differentiation and inflammation in response to stimulation of tumor necrosis factor receptor (TNFR) family, pattern-recognition receptors (PRRs), and some cytokine receptors. They are able to control the activity, the cellular fate, or the stability of actors of signaling pathways, acting at different levels from components of receptor-associated multiprotein complexes to signaling effectors and transcription factors, as well as cytoskeleton regulators. Much less is known about ubiquitination substrates involved in non-immune signaling pathways. This review aimed to present IAP ubiquitination substrates and the role of IAP-mediated ubiquitination in regulating signaling pathways.
\end{abstract}

Keywords: IAP; ubiquitination; cell signaling; inflammation

\section{Introduction}

IAPs (Inhibitors of Apoptosis) constitute a family of conserved proteins found in a variety of organisms including virus, yeast, fungus, worms, insects, arthropods, fish, and mammals [1-6]. They were discovered in baculovirus in a genetic screen aiming to identify viral proteins able to prevent the death of infected cells [1]. Mammal IAPs share this anti-apoptotic property (for review, see Reference [7]). However, most of them function primarily as cell signaling regulators [8,9]. cIAP1 (cellular IAP1), cIAP2, and XIAP (X-linked IAP) are potent regulators of innate immune response [10]. They control the activation of NF-KB (nuclear factor kappa-light-chain-enhancer of activated B cells) and MAPK (mitogen activated protein (MAP) kinase) signaling pathways in response to the stimulation of members of the tumor necrosis factor receptor (TNFR) superfamily, pattern-recognition receptors (PRRs), or some cytokine receptors. Their signaling activity is directly related to their ability to promote ubiquitination of key signaling intermediates [11].

Ubiquitination is a post-translational modification initially described as the principal way to regulate the half-life of proteins and to clear defective and misfolded proteins. The Nobel Prize rewarded the discovery of ubiquitin-mediated protein degradation by Aaron Ciechanover, Avram Hershko, and Irvin Rose in 2004. Since then, the increasing interest of researchers for the ubiquitin system has considerably enlarged the spectral of action of this modification, which has ultimately appeared as a very complex system able not only to control the protein turnover but also to ensure spatiotemporal signal transduction and dynamic communication within the cells. Because they can be implemented very quickly, they constitute a remarkable and effective protein-regulating system employed in the first line of defense by cells to cope with changing cellular environment. They largely 
contribute to the adaptation of cell behavior to physiological intracellular variations, as well as to intracellular or environmental stresses.

Out of the eight IAPs found in mammals, cIAP1, cIAP2, XIAP, ML-IAP (Melanoma IAP also named livin), and ILP2 (IAP-like protein 2) are component of the ubiquitination machinery by acting as E3-ubiquitine ligases. They can catalyze the conjugation of K6, K11, K27, K48, and K63-linked ubiquitin chains [12-15], as well as mono-ubiquitination [16-19]. They can promote the conjugation of diverse ubiquitin-linked chains on the same substrate leading to variable cellular fate [20]. The conjugation of the ubiquitin-like modifier NEDD8 (neural precursor cell expressed developmentally downregulated protein 8) by IAPs has even been observed [21]. Many IAP-ubiquitination substrates involved in various cellular processes have been reported. Although the role of IAPs in immune response has started to be well characterized, little is known about their function in other signaling pathways (e.g., autophagy, DNA damage response, transcriptional regulation, etc.). This review is an overview of the most documented IAP ubiquitination substrates and the role of IAP-mediated protein modifications in regulating cell signaling.

\section{The Ubiquitin System}

Typically, ubiquitination consists in the covalent conjugation of ubiquitin moieties on a lysine residue from an intracellular protein substrate. Ubiquitin is a 76 amino-acid peptide that contains seven lysine residues (K6, K11, K27, K29, K33, K48, K63) that, just like the amino-terminal Methionine (M1), behave as acceptor residues for ubiquitin moieties. Thus, intracellular proteins can be modified by a single ubiquitin molecule (monoubiquitination) or multimeric ubiquitin chains (polyubiquitination) of variable topologies conferring specific properties to the modified proteins. Moreover, one protein substrate can be modified on several lysine residues, and the location of the modification is also determinant to modulate the properties of the protein [22]. Ubiquitin moieties are specifically recognized by effector proteins harboring linkage-specific ubiquitin-binding modules that engage in downstream events. For example, proteins modified by conjugation of homotypic K48-linked ubiquitin chains are guided toward the proteasome for degradation, homotypic K63-, or the linear homotypic M1-linked ubiquitin chains are signals for the assembly of intracellular multiprotein signaling platforms, while the mono-ubiquitination of cell-surface receptors triggers their internalization and subsequent lysosomal degradation. Recent observations revealing the presence of mixed chains (composed of multiple linkages), branched chains (in which one ubiquitin unit is modified at two or more acceptor sites), or ubiquitination at non-lysine sites in substrate [23] have added a level of complexity to the ubiquitin code [24].

Ubiquitin conjugation is a three-step multi-enzymatic reaction. The first step involves an E1 enzyme that activates, in an ATP-dependent manner, the C-terminus of ubiquitin. Once activated, ubiquitin is transferred to the active cysteine residue of an E2-conjugating enzyme to form an E2-ubiquitin thioester conjugate. E3-ubiquitine ligases promote the ubiquitin transfer from E2s to the substrate [25]. Additional ubiquitins can be tethered to acceptor residues of ubiquitin to form ubiquitin chains. It is generally admitted that E3s support substrate recognition and determine the specific site of the modification, while E2s play a major role in determining the type of ubiquitin chain linkage. However, E3s can also contribute in linkage specificity, particularly in the case of mixed or branched chains, by employing different E2s to elongate the polyubiquitin chain [24-27].

\section{IAP E3-Ubiquitine Ligases}

\subsection{IAP Structure}

IAPs are defined by the presence of one to three specific evolutionary conserved domains named BIR (baculovirus IAP repeat), whose function is protein-protein interaction (Figure 1a,b). cIAP1, cIAP2, and XIAP contain three tandem repeats of BIRs, while ML-IAP and ILP2 display one unique BIR (Figure 1a). These are compact domains composed of approximately 80 amino-acid residues structured 
in 3 short $\beta$-strands and 4-5 $\alpha$-helices (Figure $1 b$ ). In most of them (except the BIR1 of cIAPs and XIAP), the $\beta$-strands and the third $\alpha$-helix form a deep hydrophobic groove that specifically anchors a 4 amino-acid linear motif called IBM (IAP binding motif). The main characteristic of IBMs is the presence of an N-terminal alanine or, for a few of them, a serine residue that has to be exposed to fit into the BIR pocket. IBM has been found in numerous mitochondrial proteins [28], including the second mitochondria-derived activator of caspase (Smac) [29,30], for which the IBM is exposed after removing of the $\mathrm{N}$-terminal mitochondrial targeting motif during its proteolytic maturation process. IBM of non-mitochondrial proteins is located just downstream of the initiating methionine removal by methionine aminopeptidases (in the case of the NF-kappa-B (NF-kB)-inducing kinase (NIK) and the checkpoint kinase 1 (chk1) [31,32] or is exposed at the N-terminal extremity of the cleavage product upon caspase- or calpain-mediating processing during apoptosis or reticular stress respectively (in the case of caspase 3, 7, or 9 or the releasing factor eRF3/GSTP) [33-35]. Deciphering the mechanisms of interaction of Smac with the BIRs led to the design of IAP antagonists named Smac mimetics able to bind both the BIR2 and the BIR3 domains (see the reviews in Reference [36,37]). Alternative modes of interaction also exist. The cIAP1-BIR3 can bind protein partners by using unconventional IBMs [38] or another BIR-binding interface [39]. In addition, the BIR1 of cIAP1/2 and XIAP that are unable to anchor IBM bind the signaling adaptor tumor necrosis factor receptor (TNFR)-associated factor 2 (TRAF2) [40,41] and the transforming growth factor-activated kinase 1-binding protein 1 (TAB1) [42], respectively.

(a)

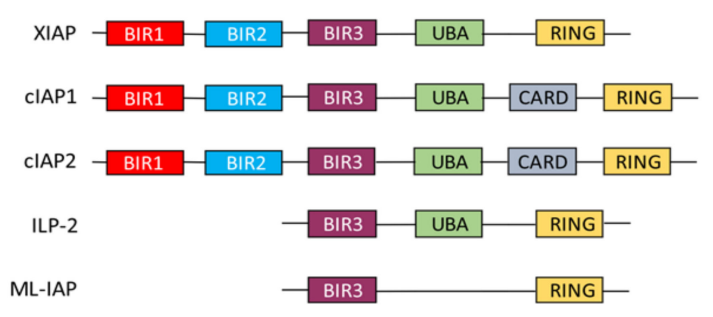

(b)

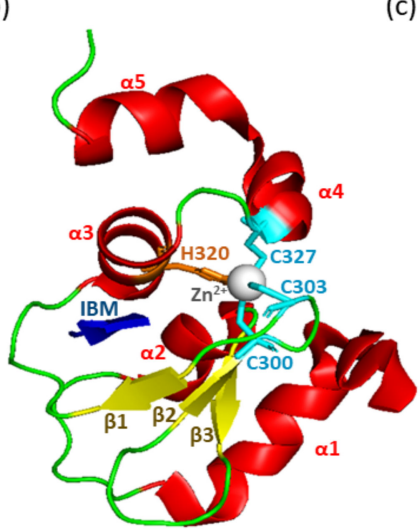

(c)

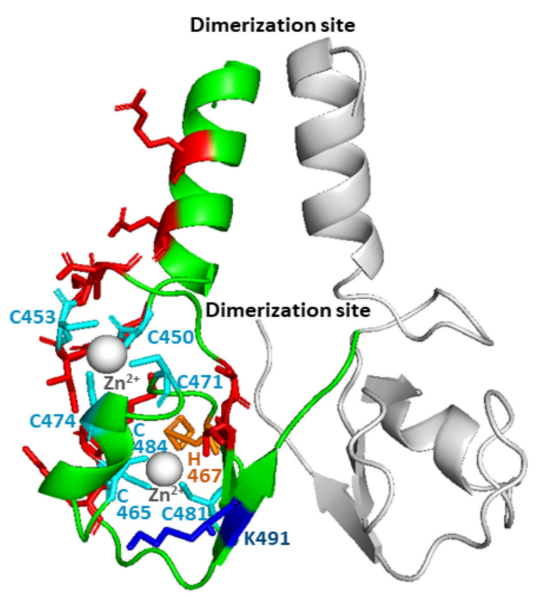

Figure 1. (a) Structure of Inhibitor of Apoptosis (IAP) E3-ubiquitine ligases. BIR: Baculovirus IAP repeat; UBA: ubiquitin associated; CARD: caspase activation and recruitment domain; RING: really interesting gene. (b) Ribbon diagram of the cIAP1 BIR3 domain in contact with the IAP binding motif (IBM) of caspase 9 . The sheets $(\beta)$ are shown as yellow ribbons and helixes $(\alpha)$ as red ribbons. $\beta$-strands and the third $\alpha$-helix form a deep hydrophobic groove stabilized by zinc atom (grey spheres) that is coordinated by three conserved Cysteine (cyan) and one Histidine (orange) residues. The IBM is represented in blue. (c) Ribbon diagram of an X-linked IAP (XIAP)-RING domain homodimer. The zinc ions are shown as grey spheres, the cysteine residues interacting with zinc as cyan sticks, the histidine as orange sticks, the ubiquitin-interacting site as blue sticks, and the E2-interacting sites as red sticks. 
The BIRs serve as ubiquitination substrate binding components. Alternatively, substrates can be recruited through adaptors or intermediates, such as TRAF2, TRAF3 [43-45], the PHD-bromodomain 1 (TRIP-Br1, Sertad1) [15], or the septin-like ARTS (Apoptosis Related protein in transforming growth factor (TGF)-beta signaling pathway) [46].

The E3-ubiquitine ligase activity of cIAP1, cIAP2, XIAP, ML-IAP and ILP2 is supported by the C-terminal RING domain [11] (Figure 1c). RING is the most widespread E3 active domain. It is structured as a zinc finger platform for bringing in close proximity both the ubiquitin-charged E2 and the substrate [47] (Figure 1c). It catalyzes the transfers of ubiquitin moieties from the E2 to a Lysine of the substrate without intermediate conjugation of ubiquitin to E3.

In addition to the BIRs and RING, cIAPs, XIAP, and ILP2 bear a ubiquitin associated (UBA) domain and cIAPs a caspase activation and recruitment domain (CARD) [11]. The CARD regulates the activating dimerization of cIAPs (see below) [48,49], while the UBA is an ubiquitin binding domain allowing the recruitment of IAPs to signaling complex [50,51]. The UBA is also able to bind ubiquitin-charged E2s suggesting that UBA could contribute in the choice of the E2s, therefore determining the type of ubiquitin chain linkage [12,52].

\subsection{IAP E3-Ubiquitine Ligase Activity}

As observed for many RING-finger E3s, a dimerization of IAPs is required for transferring ubiquitin from E2s to the substrate (for review, see Reference [11]). The dimerization interface is located at the extreme C-terminus of the RING (Figure 1c). A crystallographic analysis of a construct encoding the C-part of cIAP1 that includes the BIR3, the RING, and the two intermediate domains, UBA and CARD, revealed that the monomeric cIAP1 adopts a compact inactive closed conformation, in which the RING is sequestered in the heart of the molecule [48]. The monomeric form can bind ubiquitin-charged E2s; however, this binding is not sufficient to promote dimerization [53] nor ubiquitin transfer [54]. The BIR3 and CARD are both critical for maintaining the closed auto-inhibited conformation [49]. Engagement of the BIR3 by synthetic ligands (e.g., Smac mimetics) promotes a cIAP1 conformational modification and RING exposure, resulting in dimerization and subsequent E3-ligase activation, auto-ubiquitination, and degradation [48,54]. A dynamic analysis of cIAP1 conformational change and inter-domain motions suggested that CIAP1 is prime for activation and able to undergo a very rapid activating conformational change upon binding of ligands [54]. When overexpressed in HEK293T cells, cIAPs are unstable proteins because of autoubiquitination and degradation, suggesting their tendency to spontaneously dimerize [55]. Co-expressing the molecular adapter TRAF2 with cIAP1 blocked the cIAP1-auto-ubiquitination process, stabilized the protein [55] and regulated its subcellular localization [56], demonstrating the importance of TRAF2 as regulatory partner of cIAP1. By contrast, the dimeric form of XIAP that does not contain CARD is stable and does not require an activation step [57].

\subsection{The cIAPs-TRAF2-TRAF3 E3-Ubiquitin Ligase Complex}

TRAFs constitute a family of cytoplasmic adaptors involved in signal transduction from a variety of receptors involved in immune response [58]. Just like cIAPs, TRAF1 and 2 were discovery in a biochemical screen aiming to identify cytoplasmic proteins associated with the tumor necrosis factor Receptor 2 (TNFR2) [59]. Since then, 4 other members have been described in mammals, characterized by the structural similarity. They share the presence in protein structure of a specific TRAF domain which function is protein-protein interaction. It binds to receptors by its $\mathrm{N}$-extremity (TRAF-N domain) and to intracellular signaling molecules through its C-extremity (named TRAF-C). The functional form of TRAF proteins is a trimer that binds to trimeric active receptors and connects downstream signaling effectors. Beside this scaffolding function, TRAF2-6 also display an E3-ubiquitin ligase activity thanks to the presence of an N-terminal RING domain [58].

Among TRAFs, TRAF2 can directly bind cIAPs, whereas TRAF1 and TRAF3 can bind cIAPs indirectly via TRAF2. The mechanisms of cIAPs-TRAF2 interaction have been extensively analyzed 
and involved the BIR1 domain. Biochemical and structural studies demonstrated that one cIAP2-BIR1 molecule binds TRAF2 in its trimeric functional form [41]. TRAF2 promotes the recruitment of cIAPs into receptors associated signaling complexes, thereby engaging downstream signaling pathways. The concerned receptors are TNFR1, TNFR2, CD40, CD30, and BAFF-R (B-cell activating factor) from the TNFR superfamily, TLR4 (toll-like receptor-4), nucleotide binding-oligomerization domain (NOD)-like receptors (NLRs), retinoic acid-inducible gene I (RIG-I)-like receptors (RLRs), and some cytokine receptors, such as interferon (IFN) receptor [58,60]. Independently of receptor engagement, cIAP1 has been found associated with TRAF2 in unstimulated cells from several linages, including epithelial cells, lymphocytes, macrophages, and murine embryonic fibroblasts (MEF) [43,61,62].

Increasing evidences suggest that cIAP1 and TRAF2 form an E3-ubiquitin ligase complex, in which cIAP1 functions as E3-enzyme, while TRAF2 constitutes an important regulatory subunit. TRAF2 serves as adaptor for bringing cIAP1 to close proximity of the substrates, it can stabilize cIAP1 by blocking auto-ubiquitination process [55], regulates its subcellular localization [56], and also activates its E3-ubiquitine ligase activity through K63-linked ubiquitination [63]. In some situation, TRAF3 takes part in the complex serving as substrate binding component (Table 1).

Table 1. IAP ubiquitination substrates.

\begin{tabular}{|c|c|c|c|c|c|}
\hline $\begin{array}{c}\text { Cellular } \\
\text { Process } \\
\text { /Protein } \\
\text { Family }\end{array}$ & $\begin{array}{l}\text { Substrate } \\
\text { or Partner }\end{array}$ & IAPs & $\begin{array}{l}\text { Interacting } \\
\text { Mode }\end{array}$ & Nature of the Ubiquitination/Consequences & Ref \\
\hline \multirow[t]{12}{*}{ Apoptosis } & AIF & XIAP & BIR2 & $\begin{array}{l}\text { Degradative polyubiquitination \& } \\
\text { Nondegradative polyubiquitination at K255 } \\
\text { interfering with AIF DNA binding. }\end{array}$ & {$[64,65]$} \\
\hline & ARTS & XIAP & BIR3 & $\begin{array}{l}\text { Degradative polyubiquitination at K3, blocks } \\
\text { XIAP inhibition }\end{array}$ & [66] \\
\hline & Bcl2 & XIAP & $\begin{array}{l}\text { Indirect, } \\
\text { via ARTS }\end{array}$ & Degradative ubiquitination favoring cell death & [46] \\
\hline & \multirow{2}{*}{$\begin{array}{l}\text { Caspase-3 } \\
\text { and }-7\end{array}$} & cIAP2 & Direct & Mono-ubiquitination in in vitro assay & [16] \\
\hline & & $\begin{array}{l}\text { cIAP1, } \\
\text { XIAP }\end{array}$ & \multirow[t]{3}{*}{$\begin{array}{l}\text { BIR2, } \\
\text { IBM-dep. }\end{array}$} & $\begin{array}{l}\text { K48-linked polyubiquitination inhibiting cell } \\
\text { death }\end{array}$ & {$[67,68]$} \\
\hline & Caspase-7 & XIAP & & Neddylation, inhibition of caspase activity & [21] \\
\hline & Caspase- 8 & $\begin{array}{l}\text { CIAP1, } \\
\text { XIAP }\end{array}$ & & $\begin{array}{c}\text { Degradative ubiquitination of component of the } \\
\text { Ripoptosome }\end{array}$ & [69] \\
\hline & cIAP1/2 & cIAP1 & \multirow{3}{*}{ BIR1-3 } & $\begin{array}{c}\text { Degradative (auto)ubiquitination, required } \\
\text { TRAF2 }\end{array}$ & {$[70,71]$} \\
\hline & FAF1 & XIAP & & $\begin{array}{l}\text { Degradative polyubiquitination, inhibits } \\
\text { FAF1-mediated cell death }\end{array}$ & [72] \\
\hline & $\operatorname{FLIP}_{\mathrm{L}}$ & $\begin{array}{l}\text { cIAP1, } \\
\text { XIAP }\end{array}$ & & $\begin{array}{l}\text { Degradative ubiquitination of component of the } \\
\text { Ripoptosome. Ubiquitination of FLIP required } \\
\text { caspase-8-mediated cleavage. }\end{array}$ & [69] \\
\hline & Smac & $\begin{array}{l}\text { cIAPs, } \\
\text { XIAP }\end{array}$ & \multirow[t]{2}{*}{$\begin{array}{l}\text { BIR2,3, } \\
\text { IBM-dep. }\end{array}$} & $\begin{array}{l}\text { Degradative ubiquitination, blocks XIAP } \\
\text { inhibition and inhibits cell death }\end{array}$ & {$[73,74]$} \\
\hline & XIAP & XIAP & & Degradative autoubiquitination & [70] \\
\hline Autophagy & p62 & XIAP & Direct & Degradative ubiquitination & [75] \\
\hline \multirow{2}{*}{$\begin{array}{l}\text { Copper } \\
\text { homeostasis }\end{array}$} & CCS & XIAP & BIR3 & $\begin{array}{l}\text { Polyubiquitination at K241, enhances chaperone } \\
\text { activity }\end{array}$ & [76] \\
\hline & COMMD1 & XIAP & BIR3 & $\begin{array}{l}\text { K48-linked ubiquitination, Increases intracellular } \\
\text { copper in cultured cell }\end{array}$ & [77] \\
\hline \multirow{6}{*}{$\begin{array}{l}\text { Cytoskeleton } \\
\text { regulation }\end{array}$} & $\operatorname{cdc} 42$ & XIAP & Direct & Degradative polyubiquitination at K166 & [78] \\
\hline & & cIAP1 & BIR2 & $\begin{array}{l}\text { Stabilization of RhoGDI } \alpha \text {-cdc } 42 \text { interaction. } \\
\text { Regulation of the TNF } \alpha \text { EGR or } \\
\text { Ras-V12-mediated activation }\end{array}$ & [61] \\
\hline & Profilin 2 & cIAP1 & Direct & Degradative polyubiquitination & [79] \\
\hline & Rac1 & XIAP, & BIR1-2 & Degradative polyubiquitination at K147 & [80] \\
\hline & & cIAPs & & Upregulation and activation of Rac1 & [81] \\
\hline & RhoA & XIAP & Direct & $\begin{array}{l}\text { Regulation of protease-activated } \\
\text { receptor-mediated RhoA activation }\end{array}$ & [82] \\
\hline
\end{tabular}


Table 1. Cont.

\begin{tabular}{|c|c|c|c|c|c|}
\hline $\begin{array}{l}\text { Cellular } \\
\text { Process } \\
\text { /Protein } \\
\text { Family }\end{array}$ & $\begin{array}{l}\text { Substrate } \\
\text { or Partner }\end{array}$ & IAPs & $\begin{array}{l}\text { Interacting } \\
\text { Mode }\end{array}$ & Nature of the Ubiquitination/ Consequences & Ref \\
\hline \multirow{4}{*}{$\begin{array}{l}\text { DNA } \\
\text { damage } \\
\text { response/ } \\
\text { cell cycle } \\
\text { regulation }\end{array}$} & Chk1 & XIAP & $\begin{array}{l}\text { BIR3, } \\
\text { IBM-dep. }\end{array}$ & $\begin{array}{l}\text { Positive or negative modulation of the stability, } \\
\text { regulated by XAF1 }\end{array}$ & {$[32,83]$} \\
\hline & MRE11 & cIAP2 & BIRs & Direct or indirect degradative polyubiquitination & [84] \\
\hline & p21 & cIAP1 & & $\begin{array}{c}\text { Direct or indirect modulation of the neddylation } \\
\text { leading to degradation }\end{array}$ & [85] \\
\hline & Survivin & XIAP & Direct & Degradative ubiquitination, regulated by XAF1 & [86] \\
\hline \multirow{5}{*}{$\begin{array}{l}\text { Inflammation } \\
\text { NF- } \mathrm{B} B\end{array}$} & Caspase-1 & cIAP1/2 & BIR1 & K63-linked activating ubiquitination & [87] \\
\hline & SOCS1 & XIAP & BIR1 & K63-linked ubiquitination leading to stabilization & [88] \\
\hline & $\mathrm{IKK} \varepsilon$ & $\begin{array}{l}\text { CIAPs } \\
\text { /TRAF2 }\end{array}$ & & $\begin{array}{c}\text { K63-linked ubiquitination at K30, K401, essential } \\
\text { of kinase activity. }\end{array}$ & [44] \\
\hline & $\mathrm{IKK} \gamma$ & cIAP1 & BIR2-3 & $\begin{array}{l}\text { K6-polyubiquitination, mono-ubiquitination at } \\
\text { K285 and K63-linked polyubiquitination at K277 } \\
\text { and K309 leading to NF-kB activation. }\end{array}$ & $\begin{array}{l}{[18,19,} \\
89]\end{array}$ \\
\hline & NIK & cIAPs & $\begin{array}{l}\text { BIR2 and } \\
\text { indirect } \\
\text { (TRAF2/3) }\end{array}$ & K48-linked degradative ubiquitination & {$[31]$} \\
\hline \multirow[t]{4}{*}{$\begin{array}{l}\text { RIPK } \\
\text { family }\end{array}$} & RIPK1 & cIAPs & $\begin{array}{l}\text { Direct or } \\
\text { indirect }\end{array}$ & $\begin{array}{l}\text { K11 and K63-linked ubiquitination leading to } \\
\text { LUBAC recruitment and NF-KB activation. } \\
\text { Degradative K48-linked polyubiquitination. }\end{array}$ & $\begin{array}{l}{[12,13,} \\
69,90]\end{array}$ \\
\hline & RIPK2 & XIAP & BIR2 & $\begin{array}{l}\text { K63-linked ubiquitination leading to LUBAC and } \\
\text { TAK1/TAB1/TAB2 complex recruitment and } \\
\text { NF-kB activation in NOD signaling }\end{array}$ & [20] \\
\hline & RIPK2/3 & $\begin{array}{l}\text { cIAPs, } \\
\text { XIAP }\end{array}$ & & $\begin{array}{l}\text { Polyubiquitination (diverse ubiquitin chains) } \\
\text { in vitro assay }\end{array}$ & {$[14]$} \\
\hline & RIPK4 & cIAP1 & Direct & $\begin{array}{l}\text { Polyubiquitination (diverse chains) at K51 and } \\
\text { K145, in vitro assay. }\end{array}$ & {$[14]$} \\
\hline \multirow{7}{*}{$\begin{array}{l}\text { Signal } \\
\text { transduction }\end{array}$} & ACs & XIAP & $\begin{array}{l}\text { Indirect via } \\
\text { TRIP-Br1 }\end{array}$ & $\begin{array}{c}\text { K27-linked polyubiquitination at K1047 (AC1) } \\
\text { leading to enhanced AC1 endocytosis and } \\
\text { degradation }\end{array}$ & [15] \\
\hline & Bcl10 & cIAP1/2 & & $\begin{array}{c}\text { K63-linked ubiquitination leading to recruitment } \\
\text { of LUBAC and IKK complex and NF-kB } \\
\text { activation in BCR signaling }\end{array}$ & [91] \\
\hline & MEKK2/3 & $\begin{array}{l}\text { CIAP1, } \\
\text { XIAP }\end{array}$ & BIR1-2 & $\begin{array}{l}\text { K63-linked ubiquitination that blocks the } \\
\text { MEKK2/3-MEK5-ERK5 cascade }\end{array}$ & [92] \\
\hline & MEKK2 & XIAP & $?$ & $\begin{array}{l}\text { K48- and K63-linked ubiquitination, regulation } \\
\text { of the bi-phasic NF- } \kappa B \text { activation }\end{array}$ & [93] \\
\hline & PTEN & XIAP & Direct & Degradative polyubiquitination & [94] \\
\hline & RAF1 & $\begin{array}{l}\text { XIAP, } \\
\text { CIAPs }\end{array}$ & BIR1-2 & Degradative polyubiquitination & [95] \\
\hline & TAK1 & XIAP & $\begin{array}{l}\text { Direct or } \\
\text { indirect via } \\
\text { TAB1 }\end{array}$ & $\begin{array}{c}\text { K63-linked ubiquitination that results in kinase } \\
\text { activation/Degradative K48-linked } \\
\text { ubiquitination. }\end{array}$ & {$[96,97]$} \\
\hline \multirow[t]{3}{*}{$\begin{array}{l}\text { TRAF } \\
\text { family }\end{array}$} & TRAF2 & cIAP1 & BIR1 & $\begin{array}{c}\text { Degradative and non degradative } \\
\text { polyubiquitination. Regulation of receptor } \\
\text { complex mediated signaling. }\end{array}$ & {$[98,99]$} \\
\hline & TRAF3 & cIAPs & $\begin{array}{l}\text { Indirect, via } \\
\text { TRAF2 }\end{array}$ & $\begin{array}{l}\text { K48-linked degradative ubiquitination leading to } \\
\text { non-canonical NF-kB activation. } \\
\text { K48-linked polyubiquitination. K63-linked }\end{array}$ & $\begin{array}{c}{[63,100,} \\
101]\end{array}$ \\
\hline & TRAF6 & cIAPs & Indirect & $\begin{array}{c}\text { ubiquitination. Regulation of receptor complex- } \\
\text { mediated signaling. }\end{array}$ & [102] \\
\hline
\end{tabular}


Table 1. Cont.

\begin{tabular}{|c|c|c|c|c|c|}
\hline $\begin{array}{c}\text { Cellular } \\
\text { Process } \\
\text { /Protein } \\
\text { Family }\end{array}$ & $\begin{array}{l}\text { Substrate } \\
\text { or Partner }\end{array}$ & IAPs & $\begin{array}{l}\text { Interacting } \\
\text { Mode }\end{array}$ & Nature of the Ubiquitination/ Consequences & Ref \\
\hline \multirow[t]{9}{*}{$\begin{array}{l}\text { Transcriptional } \\
\text { program }\end{array}$} & $\mathrm{CHOP}$ & cIAP1 & Direct & $\begin{array}{c}\text { Degradative ubiquitination, prevents ER-stress } \\
\text { mediated apoptosis. }\end{array}$ & [103] \\
\hline & CREB & cIAPs & $\begin{array}{l}\text { Indirect, via } \\
\text { TRAF2/3 }\end{array}$ & K48-linked degradative ubiquitination & [45] \\
\hline & c-Rel & cIAPs & $\begin{array}{l}\text { Indirect, via } \\
\text { TRAF2/3 }\end{array}$ & K48-linked ubiquitination & [43] \\
\hline & E2F1 & cIAP1 & BIR3 & $\begin{array}{l}\text { K63-linked ubiquitination at K161/164. } \\
\text { Stabilization in S phase of cell cycle or upon } \\
\text { genotoxic stress. Binding to chromatin }\end{array}$ & $\begin{array}{l}{[104,} \\
105]\end{array}$ \\
\hline & Groucho & XIAP & Direct & $\begin{array}{l}\text { Monoubiquitination leading to a decrease of the } \\
\text { affinity of Groucho for transcription factor }\end{array}$ & [17] \\
\hline & $\mathrm{HIF} 1 \alpha$ & XIAP & & $\begin{array}{l}\text { K63-linked ubiquitination. Stabilization, nuclear } \\
\text { translocation. Binding to chromatin }\end{array}$ & [106] \\
\hline & IRF1 & cIAP2 & Direct & $\begin{array}{l}\text { K63-linked ubiquitination leading to } \\
\text { transcription factor activation. Regulated by S1P. }\end{array}$ & [107] \\
\hline & IRF5 & cIAPs & $\begin{array}{l}\text { Indirect, via } \\
\text { TRAF2/3 }\end{array}$ & K48-linked ubiquitination & [43] \\
\hline & Mad1 & CIAP1 & BIR1-3 & Degradative ubiquitination. Activation of c-Myc & [108] \\
\hline
\end{tabular}

ACs (Adenylyl cyclased): enzyme generating cAMP; AIF (Apoptosis-inducing factor): regulator of chromatin condensation; ARTS: septin-like mitochondrial protein promoting apoptosis by antagonizing XIAP; Bcl2 (B-cell lymphoma 2): inhibitor of the intrinsic pathway of apoptosis; Bcl10 (B-cell lymphoma 10): adaptor protein in B cell receptor (BCR)-associated complex; BIR (baculovirus IAP repeat); CCS (copper chaperone for superoxide dismutase): responsible for delivery copper to superoxide dismutase; cdc42 (Cell Division Cycle 42): Small GTPase from Rho family regulator of actin cytoskeleton; Chk1 (Checkpoint kinase 1): Serine/Threonine protein kinase that controls the G2/M phase transition in response to DNA damage; CHOP (C/EBP homogous protein): transcription factor activated in response to endoplasmic reticulum stress; cIAP1 (cellular IAP); COMMD1 (Copper metabolism MURR1 domain protein 1): scaffold protein involved in copper homeostasis; CREB (C-AMP Response Element-binding protein): transcription factor involved in immune response; c-Rel: NF-kB subunit; E2F1 (E2 promoter binding factor 1): transcription factor involved in G1-S cell cycle phase transition and in DNA damage response; FAF1: Fas-associated Factor 1, enhances Fas-induced apoptosis; FLIP (FADD-like IL-1 $\beta$-converting enzyme-inhibitory protein): major antiapoptotic protein; Groucho: repressing cofactor of the CTF/LEF (T-cell factor/lymphoid enhancer factor-1) transcription factor; HIF1 $\alpha$ (Hypoxia-inducible factor-1 $\alpha$ ); IAP (Inhibitor of Apoptosis); IBM (IAP binding motif); IKK (I-KB kinase); IRF1\&5 (Interferon (IFN) regulator factor 1\&5): transcription factors involved in the induction of IFN, some inflammatory cytokines and genes of inflammation and immune response; Mad1 (Mitotic arrest deficient 1): spindle assembly checkpoint (SAC) regulator, repressor of c-myc; MEKK2/3 (Mitogen-Activated protein kinase 2/3): serine/threonine protein kinase involved in MAP kinase signaling pathway; MRE11 (Meiotic Recombination 11 Homolog): nuclease involved in the homologous recombination (HR) pathway of double strand break repair; NIK (NF-KB-inducing kinase); p21 (also named CIP: CDK-interacting protein 1): cyclin-dependent kinase inhibitor (CKI) that controls the $S$ phase of cell cycle; p62: receptor for protein destined to be degraded by autophagy; Profilin 2: actin cytoskeletal regulator, mediator of synapse architecture; PTEN (phosphatase and tension homolog): regulator of the phosphatidylinositol 3-kinases (PI-3K)/Akt pathway; Rac1: Small GTPase from Rho family regulator of actin cytoskeleton; RAF1: serine/threonine-protein kinase (MAP3K) involved in Ras-RAF-ERK-MEK cascade; RIPK (receptor-interacting kinase); RhoA: Small GTPase from Rho family regulator of actin cytoskeleton; S1P (sphingosine-1-phosphate): bioactive sphingolipid; Smac (second mitochondria-derived activator of caspase): IAP inhibitor; SOCS1 (suppressor of cytokine signaling 1): inhibitor of IFNs and some cytokine signaling pathways; TAK1 (tumor growth factor- $\beta$-activated kinase 1); TRAF (tumor necrosis factor Receptor (TNFR)-associated factor); XIAP (X-linked IAP).

\section{IAP-Mediated Ubiquitination of Caspases and IAP Antagonists and Regulation of Apoptosis}

IAPs were first identified in baculovirus by their ability to block apoptosis of infected cells. In insect cells, they are essential for maintaining cell survival. Downregulation or loss of function of the drosophila IAP1 (DIAP1) is sufficient to induce caspase activation and massive apoptotic cell death in early embryo [109,110]. Mutation within the RING domain abolished the ability of DIAP1 to prevent apoptosis, demonstrating the importance of the E3-ubiquitine ligase activity $[109,110]$. DIAP1 protein exerts its anti-apoptotic function by inhibiting caspases. It can physically interact with both the initiator and effector caspases and promotes their ubiquitination that results in modulating their stability and activity [111,112]. Apoptosis occurrence requires the neutralization of DIAP1 [112]. Genetic analysis of Drosophila mutants displaying default in developmental cell death highlighted the importance of IAP 
antagonists [111,112]. These proteins share an N-terminal IBM that competes with the IBM of caspases for DIAP1 interaction. Binding of IAP antagonists to DIAP1 triggers DIAP1 auto-ubiquitination and degradation [112].

In mammals, XIAP and cIAPs are also able to bind and promote the ubiquitination of apoptotic caspases in vitro $[16,21,68]$. However, the in vivo relevance of this modification is still debated. XIAP is considered as the main direct inhibitor of caspases activity in mammals [113]. It is present in the apoptosome complex, and its binding to initiator caspase- 9 is sufficient to prevents the activating dimerization and protease activity of the caspase [114,115]. XIAP can also directly bind and inhibit effector caspases- 3 and -7 by hindering the substrate-binding pocket and blocking substrate accessibility [33,34,115-119], independently of ubiquitination process. However, the analysis of thymocytes, embryonic stem cells and fibroblasts from $\Delta$ RING mutant-bearing transgenic mice showed an increased caspase activity and an enhanced sensitivity to apoptosis suggesting the physiological requirement of the XIAP E3-ubiquitine ligase activity for caspase-inhibition [118]. Although less critical for apoptosis induction than in drosophila, IBM-containing-IAP antagonists also play a significant role in apoptosis regulation in mammals. The best characterized is Smac that can bind to both the BIR2 and BIR3 of cIAP1, cIAP2, XIAP, and ML-IAP in an IBM-dependent manner [120-122]. It is generally admitted that Smac competes with caspases for XIAP interaction, whereby abrogates caspase inhibition, while cIAPs and ML-IAP antagonize Smac-XIAP binding [113,123-125]. Moreover, Smac binding to the BIR domains stimulates cIAP1 E3-ubiquitin ligase activity, autoubiquitination, and degradation [126]. Accordingly, Smac deficiency in mice led to increased level of cIAPs demonstrating the essential role for Smac in controlling the intracellular cIAPs content [127]. In turn, ML-IAP, cIAP1, and XIAP can induce the ubiquitination and degradation of their antagonists [73,128,129].

Besides caspases and IAP antagonists, IAPs can also regulate through ubiquination other regulators of apoptosis (Table 1). For most of them, except for the B cell lymphoma 2 (Bcl-2) [46], IAP-mediated ubiquitination results in inhibiting cell death activity.

\section{IAP-Mediated Regulation of NF-KB-Signaling}

NF- $\kappa$ Bs correspond to a family of transcription factors responsible for the expression of several anti-apoptotic genes, cytokines and pro-inflammatory molecules that orchestrate the innate immunity [130]. They are activated upon stimulation of membrane or intracellular receptors, including members of the TNFR superfamily, growth factor receptors, cytokine receptors, and PRRs, as well as in response to environmental or endogenous stress. Two distinct NF- $\kappa B$ activation signaling pathways have been described: the canonical and the non-canonical (Figures 2 and 3). Schematically, the canonical pathway involved the IKK (Inhibitor of $\kappa B$ kinase) complex composed of IKK $\alpha$, IKK $\beta$, and $\operatorname{IKK} \gamma$ (Figure 2). It is activated by phosphorylation by upstream kinases including the tumor growth factor- $\beta$-activated kinase 1 (TAK1), in turn stimulating the UPS (ubiquitin-proteasome system)-mediated degradation of the inhibitor- $\mathrm{KB}(\mathrm{I}-\mathrm{KB})$ through phosphorylation. This results in the release and translocation of the NF- $\mathrm{KB}$ subunits to the nucleus where they promote a specific gene transcription program. The non-canonical pathway is independent of IKK $\beta$ and IKK $\gamma$ (Figure 3). It involves NIK that catalyzes the phosphorylation of IKK $\alpha$ homodimer leading to phosphorylation, processing, and nuclear translocation of the transcription factor [130]. 


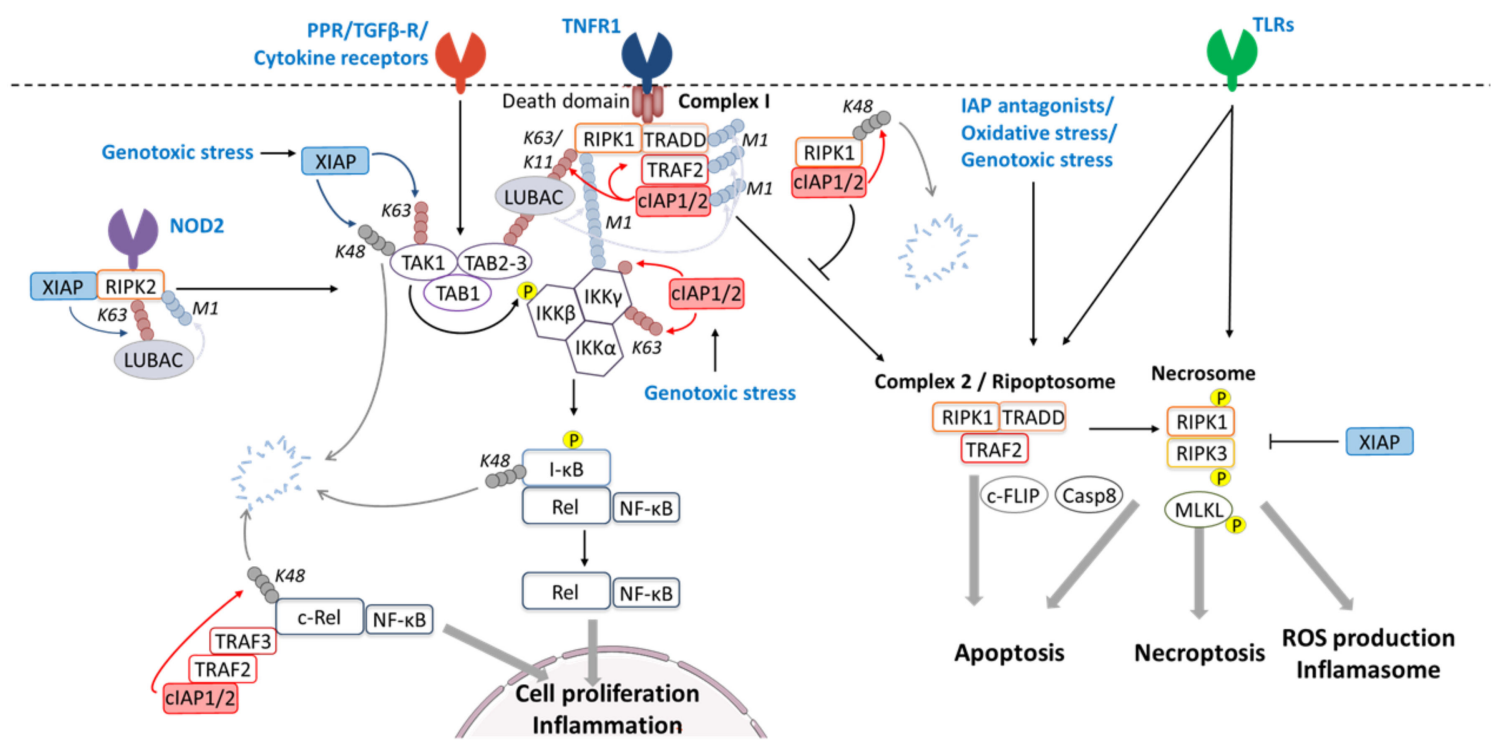

Figure 2. Regulation of the TNFR and canonical NF- $\kappa B$ signaling pathways by IAPs. The activation of the tumor necrosis factor receptor 1 (TNFR1) induces the formation of the complex 1 composed of TNFR-associated death domain (TRADD), receptor-interacting kinase 1 (RIPK1), TNFR-associated factor 2 (TRAF2), and cellular inhibitors of apoptosis (cIAP1/2). The latter promote the ubiquitination of RIPK1 (K63 and K11-linked), leading to the recruitment of the linear ubiquitin chain assembly complex (LUBAC). In turn, LUBAC induces the conjugation of linear M1-linked polyubiquitin chains to complex 1 components. The resulting ubiquitin scaffold allows the recruitment of TAK1 (tumor growth factor- $\beta$-activated kinase 1)/TAB1/TAB2/3 (transforming growth factor-activated kinase1-binding protein 1, 2, and 3) complex and IKK (Inhibitor of $\kappa B$ kinase) complex composed of IKK $\alpha / \operatorname{IKK} \beta / \mathrm{IKK} \gamma$. TAK1 catalyses the phosphorylation of IKK $\beta$ and the activation of IKK. This leads to the phosphorylation of the Inhibitor of $\kappa \mathrm{B}(\mathrm{I}-\mathrm{kB})$, its K48-linked ubiquitination, and proteasomal degradation, resulting in the release and nuclear translocation of NF- $\kappa B$ subunits. Stimulation of PRRs (pattern-recognition receptors), TGF $\beta-R$ (Transforming Growth Factor-beta receptor), cytokine receptors, NOD2 (nucleotide-binding oligomerization domain), or genotoxic stress can engage the canonical NF-kB pathways by stimulating TAK1/TAB1/TAB 2/3 complex. XIAP (X-linked inhibitor of apoptosis protein) can positively regulate TAK1 activation through K63-linked ubiquitination or negatively through K48-linked ubiquitination and proteasomal degradation. In the case of NOD2 stimulation, XIAP promotes the K63-linked ubiquitination of RIPK2 that results in the recruitment of LUBAC and TAK1 activation. cIAPs can control IKK $\gamma$ by promoting mono- or K63-linked ubiquitination, while the cIAPs/TRAFs E3-ubiquitin ligase complex can regulate c-Rel stability. A complex 2 derived from TNFR1-associated complex 1 or Ripoptosome that contain RIPK1 and RIPK3 can be formed in response to depletion of cIAPs by IAP antagonists, oxidative or genotoxic stresses, or TLRs (toll-like receptors) stimulation. Theses complexes can lead to apoptosis, necroptosis, or ROS production and inflammasome activation, depending on presence of the regulatory or effector proteins c-FLIP (cellular FLICE-like inhibitory protein), caspase 8 (Casp8), and/or MLKL. cIAPs block complex 2/ripoptosme assembly by inhibiting RIPK1 kinase activity and/or by mediating its K48-linked ubiquitination and degradation. Necrosome is negatively controlled by XIAP. 


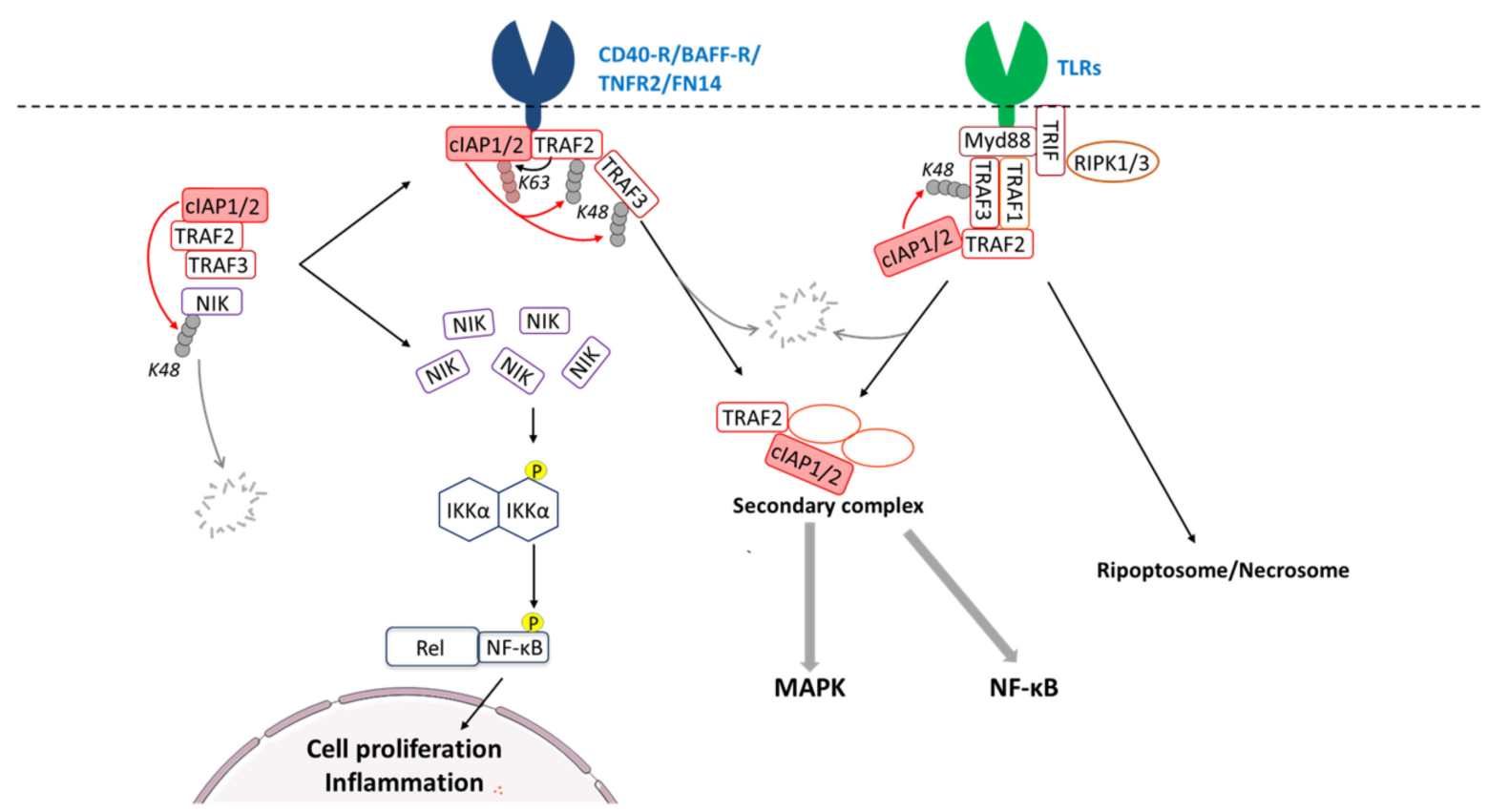

Figure 3. Regulation of signaling pathways by cIAP-mediated degradation of TRAF2 and/or TRAF3. In standing state, the cIAPs/TRAF2/3 E3-ubiquitin ligase complex controls the cellular content NIK (NF-kB-inducing kinase) by mediating K43-linked ubiquitination and proteasomal degradation. Stimulation of CD40-R (cluster of differentiation 40 receptor), BAFF-R (B-cell activating factor receptor), TNFR2 (tumor necrosis factor Receptor 2), FN14 (Fibroblast growth factor-inducible 14), or TLRs (toll-like receptors) promotes the recruitment of cIAPs/TRAFs complex to the receptor leading to the accumulation of NIK, phosphorylation of IKK $\alpha$ dimer, and activation of the non-canonical NF- $\mathrm{B}$ pathway. In receptor-associated complex, TRAF2 can stimulate cIAPs via K63-linked ubiquitination. In turn, cIAPs catalyse the K48-linked polyubiquitination of TRAF3 and, in a lower level, TRAF2, causing their degradation and the formation of a secondary complex. Upon TLR stimulation, RIPK1/3 (receptor-interacting kinase 1/3) are also recruited to the receptor complex that can lead to the assembly of Ripoptosome and/or necrosome. Myd88: Myeloid differentiation primary response 88; TRIF: toll-interleukin 1 receptor domain-containing adaptor inducing IFN- $\beta$.

\subsection{XIAP-Mediated TAK1 Ubiquitination}

TAK1 is a mitogen-activated protein kinase (MAP3K). Besides its function in transducing MAPK signaling, it can participate to NF- $\mathrm{KB}$ activation by phosphorylating IKK $\beta$. It is active when associated to TAK1-binding protein-1 (TAB1) and either TAB2 or TAB3 which share the ability of binding K63-linked ubiquitin chains [131]. Thus, TAK1/TABs complex is recruited to cell signaling platform via binding to K63-linked polyubiquitin scaffold that maintains TAK1 and its substrate in close proximity. TAK1 activation requires a direct K63-linked polyubiquitination. The E3-ubiquitin ligase TRAF6 and XIAP $[97,131]$ can mediate this modification $[97,131]$. XIAP can directly bind to TAB1 via its BIR1 domain [42,132] and induces K63-linked polyubiquitination that results in TAK1 activation and stabilization of IKK complex [89,97]. The XIAP-mediated TAK1 polyubiquitination is critical for NF- $\mathrm{kB}$ activation in response to genotoxic stress [89] and for TGF- $\beta$ (transforming growth factor beta) signaling $[97,133]$. XIAP is able to directly interact with the TGF- $\beta$ receptor type I $[97,133]$ and BMP (bone morphogenetic proteins) receptors [132], bridging the receptor to TAK-1/TABs complex and allowing the engagement of JNK (c-Jun N-terminal kinase) and NF- $\mathrm{kB}$ signaling pathways [133]. XIAP has also been involved in a feed-back loop regulation in TGF- $\beta$ signaling. Indeed, TGF- $\beta$ can induce the expression of the XIAP gene $[96,134]$. In turn, XIAP mediates the polyubiquitination and degradation of TAK-1, leading to an inhibition of TGF- $\beta$-induced JNK activation [96]. 


\section{2. cIAPs-Mediated Ubiquitination of IKK $\gamma$ and IKKE}

IKK $\gamma$ (also known as NEMO for NF- KB essential modulator) is the regulatory subunit of IKK complex. While the catalytic subunits IKK $\alpha$ and $\beta$ are activated by phosphorylation, IKK $\gamma$ is subjected to multiple post-translational modifications including monoubiquitination, K6-linked, K63-linked, M1-linked, and K63/M1 hybrid polyubiquitination [130]. Genotoxic stress or TNF $\alpha$ induce mono- or K6-linked polyubiquitination of IKK $\gamma$, respectively, which are inhibited in cIAP1-deficient cells [18,89]. Directed mutagenesis and in vitro assay demonstrated a direct interaction of the N-terminus of IKK $\gamma$ with the cIAP1 BIR2-3 domain [89] and the ability of cIAP1 to conjugate monoubiquitin at Lys285 [18] and polyubiquitin chains at Lys277 and 309 [89] (Figure 3). Of interest, the mulluscum contagiosum virus (MCV) that infects keratinocytes causing small neoplasms takes advantage of this process. The MCV MC159 protein can compete with cIAP1 for IKK $\gamma$ binding; therefore, it can inhibit K63-linked ubiquitination of IKK $\gamma$ and can suppress NF- $\mathrm{KB}$ activation [135].

CIAP1/2 in complex with TRAF2 can also mediate K63-linked ubiquitination of IKKe (also called IKBKE: inhibitor of nuclear factor $\mathrm{K}-\mathrm{B}$ kinase subunit $\varepsilon$ ) [44]. IKK $\varepsilon$ is a noncanonical member of the IKK family, a downstream effector of TLR3, RIG-1, and IFN- $\beta$ receptors. It participates in signal transduction leading to the activation of NF-KBs, IFRs (interferon (IFN) regulatory factors) or STATs (Signal Transducers and Activators of Transcription). The K63-linked ubiquitination at K30 and K401 is essential for its kinase activity and NF-KB activation [136].

\section{3. cIAP1/2-TRAF2-TRAF3 E3-Ubiquitin Ligase Complex Regulates the Cellular Content of c-Rel}

Among NF- $\mathrm{kB}$ transcription factors, the c-Rel subunit is required for TLR-induced expression of pro-inflammatory cytokines. It has been associated with inflammatory and autoimmune diseases in c-Rel knockout mouse models. The steady-level of c-Rel and its activation in response to TLR stimulation is enhanced in TRAF2-deficient myeloid cells. TRAF2 mediates UPS-dependent degradation of c-Rel, which depends on the presence of cIAP1s. cIAPs and TRAF2 can complex with c-Rel only in the presence of TRAF3. Thus, cIAPs, TRAF2, and TRAF3 cooperate to regulate the stability of c-Rel [43].

5.4. Regulation of the Cellular Content of NIK and the Non-Canonical NF-kB-Activating Signaling Pathway by the cIAP1/2-TRAF2-TRAF3 E3-Ubiquitin Ligase Complex

The development of Smac mimetics that trigger cIAP1 auto-ubiquitination and degradation has revealed the role of this IAP in the regulation of the non-canonical NF- $\mathrm{kB}$-activating signaling pathway $[137,138]$. In the standing state, the cellular content of NIK is maintained low through sustained UPS-mediated degradation process (Figure 3). Cell exposure to Smac mimetics induced NIK stabilization that resulted in the activation of the non-canonical NF-kB signaling $[137,138]$.

Genetics analysis of primary multiple myelomas that are characterized by a high level of NIK have revealed inactivating mutations in cIAP-encoding genes [139,140], which strengthen the role of cIAPs in the negative regulation of NIK. Although NIK protein contains an N-terminal IBM that can directly bind the BIR2 cIAPs, TRAF2, and TRAF3 are required for regulating NIK protein turnover [63]. The analysis of TRAFs or cIAPs mutant multiple myeloma and cIAPs- or TRAFs-deficient MEFs demonstrated that NIK degradation is ensured by the TRAF3-TRAF2-cIAP1 ubiquitin ligase complex, in which TRAF3 serves as NIK-binding component and recruits cIAPs via TRAF2 [63,141]. The NIK IBM-cIAPs interaction stabilizes the complex and facilitates the cIAP-mediated NIK degradative (K48-linked chains) ubiquitination [31].

\section{IAP-Mediated Ubiquitination of Receptor-Interacting Kinases (RIPKs)}

During the last decade, serine/threonine kinases from receptor-interacting kinase (RIPK) family had emerged as critical determinants of cell fate in response to stimulation of death, interleukin, or pattern-recognition receptors, as well as genotoxic or oxidative stresses, at the crosstalk between differentiation, inflammatory response, and cell death signaling pathways (for review, see 
Reference [142]). RIPKs are characterized by the presence of a homologous serine-threonine kinase domain (KD) and at least one additional variable domain required for the recruitment of RIPKs into receptor complexes or signaling platforms through homotypic interaction. Their cellular functions are tightly regulated by post-translational modifications, and ubiquitination constitutes one of the most important mechanism regulating their kinase activity, determining their recruitment into various multiprotein signaling complexes and modulating their ability to engage downstream signaling pathways [143-145]. cIAP1/2 and XIAP are able to catalyze the conjugation of ubiquitin chains of variable topology to RIPK1, 2, 3, and 4, but the in vivo significance of these modifications is not completely solved [14].

\section{1. cIAP1/2-Mediated RIPK1 Ubiquitination in Signal Transduction and Ripoptosome Assembly}

RIPK1 is a death domain (DD)-containing protein able to bind members of TNFR superfamily and adapter proteins via DD homotypic interaction. It determines the response of cells to receptor stimulation, controlling the activation of transcriptional response leading to survival, differentiation, and inflammation, as well as the assembly of cell death signaling platforms leading to apoptosis or necroptosis. RIPK1 can also take part to TNFR-independent signaling complexes thanks to the presence of a RIP homotypic interaction motif (RHIM) that mediates homotypic interaction with its closely related kinase RIPK3, TRIF (toll-interleukin 1 receptor domain-containing adaptor inducing IFN- $\beta$ ) that is an adaptor downstream of the pathogen-recognition receptors TLR3 and TLR4 [146] and DAI (DNA-dependent activator of interferon-regulatory factor) involved in the RIG-1 (retinoic acid-inducible gene I) signaling pathway.

The role and mechanisms of regulation of RIPK1 has been extensively studied in TNFR1 signaling pathway and recently very well reviewed [142,147] (Figure 3). Briefly, TNFR1 engagement triggers the binding of RIPK1 along with the adaptor TNFR1-associated death domain protein (TRADD) that allows the recruitment of TRAF2 and CIAP1/2 and the subsequent binding of the linear ubiquitin chain assembly complex (LUBAC). This transient membrane-associated complex referred to complex-I leads to the activation of canonical NF- $\mathrm{KB}$ and MAPK that culminate in the expression of genes promoting survival, inflammation, and differentiation. TNFR1 stimulation can also trigger the assembly of RIPK1-containing secondary cytoplasmic complexes referred to as complexes II that ultimately result in apoptotic or necroptotic cell death (Figure 3). While the kinase activity of RIPK1 is required for complexes-II assembly, it is dispensable for its scaffolding function. The ubiquitination of RIPK1 has been shown to be determinant for TNF- $\alpha$-induced NF-KB activation in some cell lines, such as Jurkat T-cells [20,69,144]. K11 and K63-linked polyubiquitin chains conjugated on the K377 residue of RIPK1 are recognized by the UBD (ubiquitin-binding domain) of the LUBAC subunit HOIP (HOIL1 (interacting protein heme-oxidized IRP2 ubiquitin ligase 1)-interacting protein) and allows the recruitment of LUBAC. In turn, LUBAC added a linear (M1-linked) ubiquitin chain to complex I components. Altogether, K11, K63, M1-linked, and hybrid poly-ubiquitin chains $[13,148,149]$ form a molecular scaffold that allows the recruitment of the trimeric kinase complexes IKK (Inhibitor of $\mathrm{KB}$ kinase composed of IKK1/2/NEMO) and TAB1/TAB2/TAK1 and ultimately results in NF- $\mathrm{B}$ and MAPK activation and gene activation (Figure 2).

CIAP1/2 and XIAP has been shown to promote K11-, K63-, and K43-linked ubiquitination of in vitro RIPK1 and in TNF- $\alpha$-treated cells $[13,14,90,149,150]$. We cannot rule out that cIAP1/2 could also mediate the conjugation of branched ubiquitin chains. Of interest, constitutive RIPK1 ubiquitination has been detected in several tumor samples including mucosa-associated lymphoid tissue lymphoma that displays a recurrent $\mathrm{t}(11 ; 18)(\mathrm{q} 21 ; \mathrm{q} 21)$ translocation involving cIAP-encoding gene [151]. Exposing cells to Smac mimetics that trigger the degradation of cIAP1 or deletion of cIAPs abrogated TNF- $\alpha$-dependent ubiquitination of RIPK1 prevented the recruitment of LUBAC, TAK1, and IKK into TNFR1-associated complex I and reduced NF-KB activation $[13,149,152]$. Although the involvement of RIPK1 in TNFR2 signaling pathway has not been clearly demonstrated, Smac mimetics can also prevent the K63-polyubiquitination of components of TNFR2 signaling complex and inhibit the 
subsequent recruitment of LUBAC and activation of canonical NF- $\mathrm{kB}$ [153]. On the other hand, double deletion of genes birc2 and birc3 (encoding cIAP1and cIAP2 respectively) or birc2 and birc4 (encoding cIAP1 and XIAP respectively) in mice led to embryogenic mortality, which is abolished or delayed by deleting RIPK1 suggesting that cIAP1 can also inhibit the pro-cell death function of RIPK1 [154]. Deletion of cIAP1/2 sensitized cells to TNF- $\alpha$, TRAIL (TNF related apoptosis inducing ligand), or Fas-mediated cell death $[137,138,155-158]$ by promoting the assembly of cytoplasmic RIPK1-containing complex-II $[152,159]$. Such a cytoplasmic complex, named Ripoptosome, can also be spontaneously formed in cells treated with IAP antagonists or can be assembled in response to microbial infection, genotoxic, or oxidative stress $[69,159,160]$. In addition to its capacity to assist the scaffolding function of RIPK1, cIAP1 represses its kinase activity and autoactivation required for the assembly of complex II or Ripoptosome [12,161]. The generation of conditional knockin mouse deleted for cIAP2 and expressing cIAP1 mutated in its UBA domain made it possible to distinguish between the cIAP1-mediated RIPK1 ubiquitination required for its scaffolding function and that controlling its kinase activity [12]. These animals developed normally but were highly sensitive to TNF-mediated cell death. UBA mutation did not affect TNF-mediated NF- KB activation but prevented the K48-linked polyubiquitination on several acceptor Lysines of RIPK1 that resulted in sustain activation and accumulation of RIPK1 and enhanced formation of complex-II leading to cell death [12]. Thus, the cIAP1-UBA seems critical in defining the type of ubiquitination and the target lysine residues. This function could be related to its ability to facilitate the recruitment of the E2-ubiquitin conjugating enzyme [52].

To summarize, cIAP1 has the ability to control the scaffolding function of RIPK1 through K11and K63-linked ubiquitination at K377, as well as its stability and kinase activity required for the cell death-inducing complex II/Ripoptosome assembly, through K48-linked ubiquitination on several ubiquitin-acceptor lysine residues (Figure 2). It constitutes a remarkable flexible checkpoint, able to determine the response to receptor engagement and to regulate the duration of the stimulation by switching the transcriptional response to cell death response or by promoting the ubiquitin-mediated degradation of RIPK1.

\subsection{Regulation of RIPK3 and Necrosome by IAPs}

In death-inducing complex II or Ripoptosome, RIPK1 binds to its closely related kinase RIPK3 through homotypic interaction via the RHIM domain, forming the so-called necrosome complex (Figure 3). Upon toll-like receptor priming by pathogen-associated molecular patterns (PAMPs), the necrosome can be formed in a cIAP-regulated RIPK1-dependent manner or independently of RIPK1 via a direct binding of RIPK3 with the adaptor TRIF [162]. Depending on the presence or not of adaptors and regulatory proteins, such as XIAP, caspase-8, cFLIPs (Cellular FADD-like IL-1 $\beta$-converting enzyme-inhibitory protein), or MLKL (Mixed lineage kinase domain like pseudokinase), necrosome can lead to apoptosis, necroptosis and even to activation of inflammasome [162-167], leading to interleukin-1 (IL-1) and -18 secretion. Both RIPK3-dependent necrosis and inflammasome activation are negatively regulated by XIAP $[163,167,168]$. Accordingly, exacerbated pathogen-associated hyper-inflammation has been observed in some patients displaying XIAP deficiency. Moreover, mice lacking cIAP1, cIAP2, and XIAP are predisposed to IL-1-dependent autoantibody-mediated arthritis [166]. Polyubiquitination, including K63-, K48-, and linear-ubiquitination of both RIPK1 and RIPK3, has been detected within the necrosome $[20,166]$. The exact mechanism and function of this ubiquitination is not clearly determined. It could maintain RIPK1 kinase activity and modulate the assembly of necrosome. Although cIAP1/2 and XIAP are able to bind and catalyze the ubiquitination of in vitro RIPK1 and RIPK3 [14], they have not been involved in such ubiquitination processes [20]. On contrarily, deletion of XIAP in bone marrow-derived dendritic cells resulted in enhanced lipopolysaccharide- and TNF $\alpha$-mediated necroptosis and inflammation [166]. Deletion of the XIAP-RING domain was sufficient to favor necrosome assembly, suggesting that XIAP functions as E3-ubiquitin ligase in regulating necroptosis. However, the ubiquitination substrates have not been determined [168]. 


\subsection{XIAP-Mediated RIPK2 Ubiquitination and Regulation of NOD1/2 Signaling Pathway}

RIPK2 protein (also named RIP2, RICK, or CARDIAK) lacks DD and RHIM domains, but it contains a CARD allowing its recruitment to the cytosolic receptors NOD1 and NOD2. NOD receptors participate to the innate immune response by sensing intracellular PAMPs. They recognize bacterial peptidoglycans and, in turn, activate pro-inflammatory and antimicrobial response via NF- $\mathrm{kB}$, ERK2, and JNK intracellular signaling pathways. Similarly, to RIPK1, the polyubiquitination of RIPK2 is critical for the recruitment and the activation of TAK1/TAB1/TAB2 and IKK complexes that drive NF-KB and MAPKs signaling pathways $[169,170]$. Among the IAP family, cIAP1/2 and XIAP are able to induce ubiquitination of RIPK2 [14]. However, XIAP seems the main determinant of NOD signal transduction. NOD2 signaling occurred normally in bone marrow-derived macrophages from cIAP1/2-compromised mice [169,171], while NOD2-dependent activation of NF- $\mathrm{BB}$ and p38MAPK and secretion of proinflammatory cytokines were impaired in XIAP-deficient myeloid cells [169,171-173]. Accordingly, mice deficient in XIAP are highly sensitive to bacteria [174]. A default in NOD1/2-dependent immune signaling had been detected in XLP2 (X-linked lymphoproliferative syndrome type-2) that is an immunodeficiency disease linked to inactivating mutation in the XIAP gene [169]. XIAP can directly interact with RIPK2 via its BIR2 domain and catalyzes the conjugation of K63-linked ubiquitin chains on K209, K410, and K538 residues located in the kinase domain $[173,175,176]$. As for RIPK1 in the TNF-signaling pathway, IAP-mediated ubiquitination of RIPK2 allows the recruitment of LUBAC, TAB1/TAB2/TAK1, and IKK complexes and ultimately triggers the activation of transcriptional response [175] (Figure 3). Interfering with XIAP-RIPK2 interaction blocked NOD2-mediated RIPK2 ubiquitination and the downstream signaling pathway [175]. A recent study demonstrated that, similarly to RIPK1 in the TNF-signaling pathway, RIPK2 can form secondary cytosolic high molecular weight complexes [176] upon NOD stimulation. These secondary RIPK2-containing complexes depend on RIPK2 kinase activity and are inhibited by XIAP-mediated ubiquitination [176].

\section{7. cIAP1-Mediated Degradation of TRAF2/3 as Regulatory Mechanism of Downstream Signaling Pathways}

Because TRAF2 is a critical intermediate in signal transduction from receptors, and TRAF3 serves as substrate binding component in the cIAPs/TRAFs E3-ubiquitin ligase complex, the modulation of TRAF2, and/or TRAF3 cellular content constitutes a very efficient mechanism of spatio-temporal regulation of signaling.

The maturation and survival of B cells are controlled by CD40 or BAFF-R-dependent activation of the non-canonical NF-KB signaling pathway. Deletion of both cIAP1 and cIAP2 in mice induced a sustained activation of non-canonical NF- $\mathrm{KB}$ and maintained B-cells survival and maturation independently of BAFF-R [177]. CD40 or BAFF-R stimulation leads to the recruitment of TRAF3-TRAF2-cIAP1/2 complex to the receptor. In the membrane-associated complex, TRAF2 promotes the K63-linked ubiquitination and activation of cIAPs. In turn, cIAPs induce K48-linked ubiquitination and degradation of TRAF3 [63] and, to a lesser extent, TRAF2 [100] that results in NIK release and engagement of canonical NF-kB signaling [63] (Figure 3). Other members of TNFR can use such mechanisms for the activation of the noncanonical NF- $\mathrm{KB}$ pathway [178]. Upon CD40 stimulation, cIAPs and TRAF2 are translocated from the membrane receptor complex into the cytosol in a cIAP-dependent manner. The cytosolic cIAP1/TRAF2 containing-complex promotes MAPK activation [100].

A cytoplasmic translocation and cIAP-mediated TRAF2 degradation have also been observed upon TNFR2 [179] or FN14 (Fibroblast growth factor-inducible 14) [180] stimulation. We demonstrated that differentiation of monocytic cells into macrophages is associated with cIAP1-induced UPS-mediated degradation of TRAF2 [62]. However, the significance of this event is still unclear. It could induce the stabilization of NIK and activation of noncanonical NF-kB and/or could constitute a feedback regulatory mechanism inhibiting canonical NF- $\mathrm{KB}$ activation [62,181-183]. Indeed, the activation of 
NF- $\mathrm{KB}$ in TNFR2-stimulated cells or along the macrophagic differentiation process is transitory, and its downregulation is critical for differentiation achievement. The NF- $\mathrm{kB}$ downregulation has been proposed to result from the cIAP1-mediated TRAF2 degradation [62].

The cIAP1-TRAF2-TRAF3 complex is also a potent regulator of TRLs signaling in macrophages $[43,101,184,185]$. TRAF1 and TRAF3 can directly bind the TRL-associated adaptor MyD88 (Myeloid differentiation primary response 88). They then recruit TRAF2-cIAP1/2 into the receptor-associated complex (Figure 3). RIPK1 and RIPK3 are also present in the complex, recruited via the adaptor TRIF (Figure 3). Depletion of cIAPs by Smac mimetics inhibited TLR2 and TLR4-induced TRAF3-degradation and MAPK signaling but did not affect noncanonical NF- $\mathrm{KB}$ [101]. As observed after CD40 stimulation [100], TLR4-associated cIAP-mediated TRAF3-degradation is followed by the cytoplasmic translocation of a secondary large cytoplasmic complex containing, among other signaling molecules, MyD88, TRAF2, and cIAP1/2, which results in canonical NF- $\mathrm{kB}$ and MAPK activation [101,185]. In the absence of cIAPs, an XIAP-regulated cytoplasmic Ripoptosome or necrosome can be formed, leading to inflammation and necroptosis [166,167].

\section{IAP-Mediated Regulation of Transcription Factors}

CIAP1 and XIAP indirectly stimulate the activation of the transcription factor Myc and CTF (T-cell factor)/LEF (lymphoid enhancer factor-1) by blocking the recruitment of their respective repressor co-factors Mad1 (Max-dimerization protein-1) and Groucho [17,108]. While cIAP1 promotes the UPS-mediated degradation of Mad1 [108], XIAP catalyzes the mono-ubiquitination of Gro/TLE resulting in a decrease affinity for the transcription factor CTF/Lef. As a consequence, XIAP favors the $\beta$-catenin-TCF/Lef complex assembly and the initiation of a Wnt-specific transcriptional program [17].

IAPs have also been involved in the regulation of the transcription factor stability. cIAP1 can catalyze the degradative ubiquitination of $\mathrm{C} / \mathrm{EBP}$ homologous protein $\mathrm{CHOP}$, a transcription factor activated in response to endoplasmic reticulum stress. Consequently, cIAP1 protects pancreatic $\beta$-cells from toxic effect of free fatty acids [103]. As previously described, cIAP/TRAFs complex controls the cellular content of c-Rel [43]. In the same way, cIAP/TRAFs complex can mediate the degradation of IFR5 [43] and CREB (C-AMP Response Element-binding protein) [45]. IFR5 and CREB, as well as c-Rel, are mediators of the immune and inflammatory response. IRFs control the expression of IFN and some pro-inflammatory cytokine genes, and CREB plays a specific function in immune response by interfering with NF-KB and IFN response, promoting survival signals in macrophages and controlling the proliferation, survival, and/or differentiation of T and B lymphocytes [186]. IRF5 and CREB can directly interact with TRAF3, which recruits TRAF2 and cIAP to promote ubiquitination and degradation of the transcription factors $[43,45]$.

A positive regulation of the transcriptional activity of IRF1, HIF1 $\alpha$ (Hypoxia-inducible factor- $1 \alpha$ ), and E2F1 (E2 promoter binding factor 1) by IAP-dependent ubiquitination processes has also been reported [104-106,187,188]. The activating process of IRFs involves post-transcriptional modifications, such as phosphorylation and K63-linked ubiquitination, which engage their dimerization and nuclear translocation. Molecular adaptors from TRAF family, mainly TRAF6, act as E3-ubiquitin ligase mediating this modification. In 2014, Harikumar et al. demonstrated that cIAP2 in complex with the bioactive sphingolipid mediator sphingosine-1-phosphate (S1P) can bind IRF1 and promotes K63-linked ubiquitination. In astrocytes, cIAP2-mediated IRF1 ubiquitination is essential for IL-1-induced IRF1-dependent expression of the chemokines CCL5 (C-C Motif Chemokine Ligand 5) and CXCL10 (C-X-C motif chemokine 10), which are involved in the recruitment of mononuclear cells to the site of inflammation [187]. HIF1 $\alpha$ participates to the adaptive response of cells exposed to stressful conditions. K63-linked ubiquitination is required for HIF1 $\alpha$ nuclear translocation and for its recruitment to target promoters. In 2017, Park et al. demonstrated that XIAP can promote this modification and is essential for the expression of HIF-dependent genes in hypoxia-stressed cells [106]. E2F1, the funding member of E2F family, is activated at the end of the G1 phase of cell cycle and promotes the expression of genes required for DNA replication and G1-S cell cycle phase transition. E2F1 also participates to the DNA 
damage response by controlling cell cycle arrest and apoptosis. The activity and turnover of E2F1 are regulated through post-translational modifications and association with co-factors and regulatory proteins [188]. The accumulation of E2F1 in S phase of cell cycle and in response to DNA damaging agents is associated with K63-linked ubiquitination at lysine 161/164 residues [105]. Studies from our group and others demonstrated the ability of IAPs to bind and regulate the transcriptional activity of E2F1 $[104,105,189,190]$. We showed that cIAP1 overexpression stabilized E2F1 protein expression and modified its ubiquitination profile, increasing the content of E2F1 modified with K11-and K63-linked polyubiquitin chains and decreasing the proportion of K48-ubiquitinated E2F1 [104]. On the other hand, the downregulation of cIAP1 inhibited the accumulation of E2F1 in S-phase-of cell cycle, as well as the one induced by genotoxic stress [105], and completely blocked its capacity to bind chromatin [104]. cIAP1 can bind E2F1 through its BIR3 domain [189] and can promote K63-linked ubiquitination [105]. Thus, IAPs-mediated K63-linked ubiquitination can act as a signal for recruiting E2F1, as well as HIF1 $\alpha$, to target promoter genes [104-106,188].

\section{IAP-Mediated Regulation of Rho-GTPases and Cytoskeleton Remodeling}

Although sometimes contradictory, numerous studies have reported modifications in the cell shape, cell polarity, or alterations in migratory or invasive behavior of cells after modulation (overexpression or downregulation) of IAP expression in mammal, drosophila, or zebrafish models (for review, see Reference [9]). The ability of IAPs to directly bind members of Rho family support these observations and may explain the divergent results $[61,80,82,191]$.

Rho GTPases are potent regulators of actin cytoskeleton that maintain cell architecture and polarization. They orchestrate the actin remodeling involved in several fundamental cellular processes, including cell adhesion, cell motility, cell migration, cell growth, cell differentiation, and cell death. Rho-GTPases constantly cycle between a cytoplasmic, inactive GDP-bound state, and an active GTP-bound state that is mainly found in membrane-associated compartments. While the inactive forms are stabilized by association with RohGDIs (RhoGDP dissociation inhibitors), in their active forms, Rho-GTPases are very unstable proteins. They are either recycled in inactive state by action of the GTPases accelerating proteins (GAPs) or ubiquitinated and degraded by the proteasome system. A function for IAP E3-ubiquitin ligases in the regulation of RhoGTPase turnover has been demonstrated $[78,80]$. XIAP can promote degradative ubiquitination of Rac1 at Lys147 [80] and cdc42 at Lys166 [78] and cIAP1 can induce ubiquitination of Rac1. Accordingly, loss of XIAP increased the cellular content of Rac1 and cdc42 in normal and tumor cell lines, therefore modifying cell morphology and migration [78,80]. On the other hand, IAP antagonists or silencing of XIAP reduced RhoA activation in response to protease-activated receptor [82], deletion of cIAP1 abolished cdc42 activation, and filopodia formation in response to TNF or EGF(Epidermal Growth Factor) [61] and the overexpression of cIAP2 led to the upregulation and activation of Rac1 in regenerating intestinal epithelial cells [81]. All studies agree that IAPs can bind RhoGTPases independently of the activation status $[61,78,82,95,191]$. We observed that cIAP1 stabilized the interaction of cdc42 with its regulator RhoGDI $\alpha$, thereby controlling cdc42 homeostasis. Similarly, to RhoGDI $\alpha$ downregulation, cIAP1 depletion sped up the activating cycle and turnover of cdc42, resulting in enhanced filopodia formation in unstimulated cells. On the other hand, cIAP1 functions as an intermediate between membrane receptor and cdc42 activation; therefore, downregulation of cIAP1 completely blocked TNF, EGF, and HRas-V12-mediated cdc42 activation and migration [61]. Thus, as observed in RIP-dependent signaling pathways, IAPs have the ability to negatively or positively regulate RhoGTPase activity and turnover in function of cellular environment and conditions.

\section{Conclusions}

Numerous studies have demonstrated the critical function for IAPs in immune response. IAP-mediated ubiquitination constitutes the foundations of ubiquitin scaffold required for the assembly of multiprotein complexes that engage signaling from several receptors involved in immune response. 
IAP-mediated ubiquitination of RIPK1 and RIPK2 in receptor-associated complex has been well documented; however, other adapters could also be IAP ubiquitination targets. For example, cIAPs-mediated ubiquitination of Bcl10 has been shown to be critical for driving BCR-mediated NF- $\kappa B$ activation [91]. Besides receptor complex, IAPs have also the ability to regulate downstream effectors, acting at different levels of signaling, from signaling kinases to transcription factors and cytoskeleton regulators. IAPs participate in signal transduction leading to cell survival, differentiation, motility, migration, and cytokine production. Thanks to their ability to promote different types of ubiquitination on substrates, they are also able to block the signaling pathways either by promoting UPS-dependent degradation of key intermediates or by switching the signal from survival to cell death. Thus, IAPs are able to modulate the strength and kinetics of signaling and to modify the cell response to a specific signal in time and space. They constitute fast and efficient adjustment parameters allowing the adaption of cells to changing conditions. The identification of IAP partners involved in cell cycle regulation, DNA damage response, copper metabolism, or autophagy (Table 1) suggests that IAPs could have more general functions in adaptive response to cellular stress.

Many of the IAP substrates remain to be identified, and the role and mechanisms of IAP-mediated ubiquitination are still misunderstood for many known partners. Determining the type and site of ubiquitination is of importance since it determines the cellular fate of proteins. Further works should be able to benefit from advances in understanding of the ubiquitin biology and from the development of new tools for investigating ubiquitination.

The mechanisms of activation and regulation of IAPs are still an important issue. IAP E3-ubiquitine ligases are actives in a dimeric form. Since IAPs are able to form heteromeric complex [192], it could be interesting to determine whether homodimers and heterodimers could have different functions. In most case, when investigated, the interplay between TRAF2 and cIAP1 was observed. TRAF2 appeared to be a very important regulator of cIAPs $[55,56,63]$. It has been observed expressed both in the cytoplasmic and nuclear fraction. Whether TRAF2 is dispensable or absolutely required for the E3-ligase activity of IAPs is still an important question to address. Some post-translational modifications of IAPs have been described, but the number of studies remains limited. Upon CD40, BAFF, or TLR4 stimulation, cIAP E3-ubiquitine ligases are activated by TRAF2 or TRAF6-mediated K63-linked ubiquitination [63,101,184]. Oxidation of the Cys308 residue in the BIR3 domain seems sufficient to trigger the dimerization, activation, and auto-ubiquitination of cIAP1 [193]. S-nitrosylation of XIAP at Cys213 within the BIR2 can modulate the anti-apoptosis function of XIAP, while S-nitrosylation of cIAP1 at Cys571 and 574 located in the RING can inhibit its E3-ubiquitine ligase activity [194]. The phosphorylation of XIAP at Ser87 or Ser40 by PKC (protein kinase C) or cdk1/Cyclin B1 complex, respectively, could modulate its stability and anti-apoptotic function $[195,196]$. The subcellular localization of IAPs seems also of importance. Most IAP substrates are cytoplasmic proteins; however, we have found that CIAP1 can be recruited to some promoters $[105,189]$, and cIAP1/2 and XIAP are able to ubiquitinate transcription factors and modulate their binding to chromatin [104,106,189]. While cIAPs are mostly located in the cytoplasm in immune cells, including lymphocytes and macrophages, we and other detected them in the nucleus of some cancer cells and undifferentiated cells (e.g., hematopoietic stem cells), and cIAP1 undergoes nuclear cytoplasmic translocation along a differentiation program [197-199].

IAPs appeared as pleiotropic proteins with cell type-specific functions. Accordingly, they have been involved in diverse human pathologies, including immune deficiencies, cancers, and inflammatory disorders [200], and IAP antagonists have entered into clinical trials for diverse clinical applications. It will be important to decipher further the specific functions and regulation mechanisms of IAPs in immune or non-immune cell subsets and to determine the impact of IAP antagonists on specific cell populations.

Author Contributions: B.D. participated to the writing and construction of the figures, A.Z. constructed the Figures and L.D. conceived and supervised the project, wrote the article with input from all authors. All authors have read and agreed to the published version of the manuscript. 
Funding: Our work is supported by grants from "La Ligue contre le cancer" Comite de la Côte d'Or ", the "Conseil Regional de Bourgogne-Franche-Comté", the French National research Agency, ("Investissements d'Avenir" program ANR-11-LABX-0021), the European Union program FEDER, and fellowships from the "Ministere de l'Enseignement Supérieur et de la Recherche" of France (AZ) and the "Fondation ARC" (BD).

Acknowledgments: We apologize to the authors that made contributions to the field but have not been cited due to space limitations. We thank Natalia Bonan-Borges for correcting reading of the manuscript.

Conflicts of Interest: The authors declare no conflict of interest.

\section{References}

1. Crook, N.E.; Clem, R.J.; Miller, L.K. An apoptosis-inhibiting baculovirus gene with a zinc finger-like motif. J. Virol. 1993, 67, 2168-2174. [CrossRef]

2. Inohara, N.; Nunez, G. Genes with homology to mammalian apoptosis regulators identified in zebrafish. Cell Death Differ. 2000, 7, 509-510. [CrossRef] [PubMed]

3. Owsianowski, E.; Walter, D.; Fahrenkrog, B. Negative regulation of apoptosis in yeast. Biochim. Biophys. Acta. 2008, 1783, 1303-1310. [CrossRef] [PubMed]

4. Qu, C.; Sun, J.; Xu, Q.; Lv, X.; Yang, W.; Wang, F.; Wang, Y.; Yi, Q.; Jia, Z.; Wang, L.; et al. An inhibitor of apoptosis protein (EsIAP1) from Chinese mitten crab Eriocheir sinensis regulates apoptosis through inhibiting the activity of EsCaspase-3/7-1. Sci. Rep. 2019, 9, 20421. [CrossRef]

5. Zhang, L.; Zhong, K.; Lv, R.; Zheng, X.; Zhang, Z.; Zhang, H. The inhibitor of apoptosis protein MoBir1 is involved in the suppression of hydrogen peroxide-induced fungal cell death, reactive oxygen species generation, and pathogenicity of rice blast fungus. Appl. Microbiol. Biotechnol. 2019, 103, 6617-6627. [CrossRef] [PubMed]

6. Chen, P.; Kang, T.T.; Bao, X.Y.; Dong, Z.Q.; Zhu, Y.; Xiao, W.F.; Pan, M.H.; Lu, C. Evolutionary and functional analyses of the interaction between the Bombyx mori inhibitor of apoptosis (IAP) and nucleopolyhedrovirus IAPs. Insect Sci. 2019. [CrossRef]

7. Berthelet, J.; Dubrez, L. Regulation of Apoptosis by Inhibitors of Apoptosis (IAPs). Cells 2013, 2, $163-187$. [CrossRef]

8. Kocab, A.J.; Duckett, C.S. Inhibitor of apoptosis proteins as intracellular signaling intermediates. FEBS J. 2016, 283, 221-231. [CrossRef]

9. Dubrez, L.; Rajalingam, K. IAPs and cell migration. Semin. Cell Dev. Biol. 2015. [CrossRef]

10. Sharma, S.; Kaufmann, T.; Biswas, S. Impact of inhibitor of apoptosis proteins on immune modulation and inflammation. Immunol. Cell Biol. 2017, 95, 236-243. [CrossRef]

11. Budhidarmo, R.; Day, C.L. IAPs: Modular regulators of cell signalling. Semin. Cell Dev. Biol. 2015, 39, 80-90. [CrossRef] [PubMed]

12. Annibaldi, A.; Wicky John, S.; Vanden Berghe, T.; Swatek, K.N.; Ruan, J.; Liccardi, G.; Bianchi, K.; Elliott, P.R.; Choi, S.M.; Van Coillie, S.; et al. Ubiquitin-Mediated Regulation of RIPK1 Kinase Activity Independent of IKK and MK2. Mol. Cell 2018, 69, 566-580.e565. [CrossRef] [PubMed]

13. Dynek, J.N.; Goncharov, T.; Dueber, E.C.; Fedorova, A.V.; Izrael-Tomasevic, A.; Phu, L.; Helgason, E.; Fairbrother, W.J.; Deshayes, K.; Kirkpatrick, D.S.; et al. c-IAP1 and UbcH5 promote K11-linked polyubiquitination of RIP1 in TNF signalling. EMBO J. 2010, 29, 4198-4209. [CrossRef]

14. Bertrand, M.J.; Lippens, S.; Staes, A.; Gilbert, B.; Roelandt, R.; De Medts, J.; Gevaert, K.; Declercq, W.; Vandenabeele, P. cIAP1/2 are direct E3 ligases conjugating diverse types of ubiquitin chains to receptor interacting proteins kinases 1 to 4 (RIP1-4). PLoS ONE 2011, 6, e22356. [CrossRef] [PubMed]

15. Hu, W.; Yu, X.; Liu, Z.; Sun, Y.; Chen, X.; Yang, X.; Li, X.; Lam, W.K.; Duan, Y.; Cao, X.; et al. The complex of TRIP-Br1 and XIAP ubiquitinates and degrades multiple adenylyl cyclase isoforms. Elife 2017, 6. [CrossRef] [PubMed]

16. Huang, H.; Joazeiro, C.A.; Bonfoco, E.; Kamada, S.; Leverson, J.D.; Hunter, T. The inhibitor of apoptosis, cIAP2, functions as a ubiquitin-protein ligase and promotes in vitro monoubiquitination of caspases 3 and 7. J. Biol. Chem. 2000, 275, 26661-26664.

17. Hanson, A.J.; Wallace, H.A.; Freeman, T.J.; Beauchamp, R.D.; Lee, L.A.; Lee, E. XIAP monoubiquitylates Groucho/TLE to promote canonical Wnt signaling. Mol. Cell 2012, 45, 619-628. [CrossRef] 
18. Hinz, M.; Stilmann, M.; Arslan, S.C.; Khanna, K.K.; Dittmar, G.; Scheidereit, C. A cytoplasmic ATM-TRAF6-cIAP1 module links nuclear DNA damage signaling to ubiquitin-mediated NF-kappaB activation. Mol. Cell 2010, 40, 63-74. [CrossRef]

19. Tang, E.D.; Wang, C.Y.; Xiong, Y.; Guan, K.L. A role for NF-kappaB essential modifier/IkappaB kinase-gamma (NEMO/IKKgamma) ubiquitination in the activation of the IkappaB kinase complex by tumor necrosis factor-alpha. J. Biol. Chem. 2003, 278, 37297-37305. [CrossRef]

20. Witt, A.; Vucic, D. Diverse ubiquitin linkages regulate RIP kinases-mediated inflammatory and cell death signaling. Cell Death Differ. 2017, 24, 1160-1171. [CrossRef]

21. Broemer, M.; Tenev, T.; Rigbolt, K.T.; Hempel, S.; Blagoev, B.; Silke, J.; Ditzel, M.; Meier, P. Systematic in vivo RNAi analysis identifies IAPs as NEDD8-E3 ligases. Mol. Cell 2010, 40, 810-822. [CrossRef] [PubMed]

22. Mattiroli, F.; Sixma, T.K. Lysine-targeting specificity in ubiquitin and ubiquitin-like modification pathways. Nat. Struct. Mol. Biol. 2014, 21, 308-316. [CrossRef] [PubMed]

23. McDowell, G.S.; Philpott, A. Non-canonical ubiquitylation: Mechanisms and consequences. Int. J. Biochem. Cell Biol. 2013, 45, 1833-1842. [CrossRef] [PubMed]

24. Yau, R.; Rape, M. The increasing complexity of the ubiquitin code. Nat. Cell Biol. 2016, 18, 579-586. [CrossRef]

25. Zheng, N.; Shabek, N. Ubiquitin Ligases: Structure, Function, and Regulation. Annu. Rev. Biochem 2017, 86, 129-157. [CrossRef]

26. Iwai, K.; Tanaka, K. Ubiquitin chain elongation: An intriguing strategy. Mol. Cell 2014, 56, 189-191. [CrossRef]

27. Ohtake, F.; Saeki, Y.; Ishido, S.; Kanno, J.; Tanaka, K. The K48-K63 Branched Ubiquitin Chain Regulates NF-kappaB Signaling. Mol. Cell 2016, 64, 251-266. [CrossRef]

28. Verhagen, A.M.; Kratina, T.K.; Hawkins, C.J.; Silke, J.; Ekert, P.G.; Vaux, D.L. Identification of mammalian mitochondrial proteins that interact with IAPs via N-terminal IAP binding motifs. Cell Death Differ. 2007, 14, 348-357. [CrossRef]

29. Silke, J.; Verhagen, A.M.; Ekert, P.G.; Vaux, D.L. Sequence as well as functional similarity for DIABLO/Smac and Grim, Reaper and Hid? Cell Death Differ. 2000, 7, 1275. [CrossRef]

30. Verhagen, A.M.; Ekert, P.G.; Pakusch, M.; Silke, J.; Connolly, L.M.; Reid, G.E.; Moritz, R.L.; Simpson, R.J.; Vaux, D.L. Identification of DIABLO, a mammalian protein that promotes apoptosis by binding to and antagonizing IAP proteins. Cell 2000, 102, 43-53. [CrossRef]

31. Lee, S.; Challa-Malladi, M.; Bratton, S.B.; Wright, C.W. Nuclear factor-kB-inducing kinase (NIK) contains an amino-terminal inhibitor of apoptosis (IAP)-binding motif (IBM) that potentiates NIK degradation by cellular IAP1 (c-IAP1). J. Biol. Chem. 2014, 289, 30680-30689. [CrossRef] [PubMed]

32. Galvan, V.; Kurakin, A.V.; Bredesen, D.E. Interaction of checkpoint kinase 1 and the X-linked inhibitor of apoptosis during mitosis. Febs Lett. 2004, 558, 57-62. [CrossRef]

33. Srinivasula, S.M.; Hegde, R.; Saleh, A.; Datta, P.; Shiozaki, E.; Chai, J.; Lee, R.A.; Robbins, P.D.; Fernandes-Alnemri, T.; Shi, Y.; et al. A conserved XIAP-interaction motif in caspase-9 and Smac/DIABLO regulates caspase activity and apoptosis. Nature 2001, 410, 112-116. [CrossRef] [PubMed]

34. Tenev, T.; Zachariou, A.; Wilson, R.; Ditzel, M.; Meier, P. IAPs are functionally non-equivalent and regulate effector caspases through distinct mechanisms. Nat. Cell Biol. 2005, 7, 70-77. [CrossRef]

35. Hashimoto, Y.; Inagaki, H.; Hoshino, S. Calpain mediates processing of the translation termination factor eRF3 into the IAP-binding isoform p-eRF3. Febs Lett. 2015, 589, 2241-2247. [CrossRef]

36. Dubrez, L.; Berthelet, J.; Glorian, V. IAP proteins as targets for drug development in oncology. Oncotargets Ther. 2013, 9, 1285-1304. [CrossRef]

37. Cossu, F.; Milani, M.; Mastrangelo, E.; Lecis, D. Targeting the BIR Domains of Inhibitor of Apoptosis (IAP) Proteins in Cancer Treatment. Comput. Struct. Biotechnol. J. 2019, 17, 142-150. [CrossRef]

38. Kurakin, A.; Bredesen, D.E. An unconventional IAP-binding motif revealed by target-assisted iterative screening (TAIS) of the BIR3-cIAP1 domain. J. Mol. Recognit. 2007, 20, 39-50. [CrossRef]

39. Bornstein, B.; Gottfried, Y.; Edison, N.; Shekhtman, A.; Lev, T.; Glaser, F.; Larisch, S. ARTS binds to a distinct domain in XIAP-BIR3 and promotes apoptosis by a mechanism that is different from other IAP-antagonists. Apoptosis 2011, 16, 869-881. [CrossRef]

40. Mace, P.D.; Smits, C.; Vaux, D.L.; Silke, J.; Day, C.L. Asymmetric recruitment of cIAPs by TRAF2. J. Mol. Biol. 2010, 400, 8-15. [CrossRef] 
41. Zheng, C.; Kabaleeswaran, V.; Wang, Y.; Cheng, G.; Wu, H. Crystal structures of the TRAF2: cIAP2 and the TRAF1: TRAF2: cIAP2 complexes: Affinity, specificity, and regulation. Mol. Cell 2010, 38, 101-113. [CrossRef] [PubMed]

42. Lu, M.; Lin, S.C.; Huang, Y.; Kang, Y.J.; Rich, R.; Lo, Y.C.; Myszka, D.; Han, J.; Wu, H. XIAP induces NF-kappaB activation via the BIR1/TAB1 interaction and BIR1 dimerization. Mol. Cell 2007, 26, 689-702. [CrossRef] [PubMed]

43. Jin, J.; Xiao, Y.; Hu, H.; Zou, Q.; Li, Y.; Gao, Y.; Ge, W.; Cheng, X.; Sun, S.C. Proinflammatory TLR signalling is regulated by a TRAF2-dependent proteolysis mechanism in macrophages. Nat. Commun. 2015, 6, 5930. [CrossRef] [PubMed]

44. Zhou, A.Y.; Shen, R.R.; Kim, E.; Lock, Y.J.; Xu, M.; Chen, Z.J.; Hahn, W.C. IKKe-mediated tumorigenesis requires K63-linked polyubiquitination by a cIAP1/cIAP2/TRAF2 E3 ubiquitin ligase complex. Cell Rep. 2013, 3, 724-733. [CrossRef] [PubMed]

45. Mambetsariev, N.; Lin, W.W.; Stunz, L.L.; Hanson, B.M.; Hildebrand, J.M.; Bishop, G.A. Nuclear TRAF3 is a negative regulator of CREB in B cells. Proc. Natl. Acad. Sci. USA 2016, 113, 1032-1037. [CrossRef]

46. Edison, N.; Curtz, Y.; Paland, N.; Mamriev, D.; Chorubczyk, N.; Haviv-Reingewertz, T.; Kfir, N.; Morgenstern, D.; Kupervaser, M.; Kagan, J.; et al. Degradation of Bcl-2 by XIAP and ARTS Promotes Apoptosis. Cell Rep. 2017, 21, 442-454. [CrossRef]

47. Deshaies, R.J.; Joazeiro, C.A. RING domain E3 ubiquitin ligases. Annu. Rev. Biochem. 2009, 78, $399-434$. [CrossRef]

48. Dueber, E.C.; Schoeffler, A.J.; Lingel, A.; Elliott, J.M.; Fedorova, A.V.; Giannetti, A.M.; Zobel, K.; Maurer, B.; Varfolomeev, E.; Wu, P.; et al. Antagonists induce a conformational change in cIAP1 that promotes autoubiquitination. Science 2011, 334, 376-380. [CrossRef]

49. Lopez, J.; John, S.W.; Tenev, T.; Rautureau, G.J.; Hinds, M.G.; Francalanci, F.; Wilson, R.; Broemer, M.; Santoro, M.M.; Day, C.L.; et al. CARD-mediated autoinhibition of cIAP1's E3 ligase activity suppresses cell proliferation and migration. Mol. Cell 2011, 42, 569-583. [CrossRef]

50. Gyrd-Hansen, M.; Darding, M.; Miasari, M.; Santoro, M.M.; Zender, L.; Xue, W.; Tenev, T.; da Fonseca, P.C.; Zvelebil, M.; Bujnicki, J.M.; et al. IAPs contain an evolutionarily conserved ubiquitin-binding domain that regulates NF-kappaB as well as cell survival and oncogenesis. Nat. Cell Biol. 2008, 10, 1309-1317. [CrossRef]

51. Blankenship, J.W.; Varfolomeev, E.; Goncharov, T.; Fedorova, A.V.; Kirkpatrick, D.S.; Izrael-Tomasevic, A.; Phu, L.; Arnott, D.; Aghajan, M.; Zobel, K.; et al. Ubiquitin binding modulates IAP antagonist-stimulated proteasomal degradation of c-IAP1 and c-IAP2(1). Biochem. J. 2009, 417, 149-160. [CrossRef]

52. Budhidarmo, R.; Day, C.L. The ubiquitin-associated domain of cellular inhibitor of apoptosis proteins facilitates ubiquitylation. J. Biol. Chem. 2014, 289, 25721-25736. [CrossRef]

53. Feltham, R.; Bettjeman, B.; Budhidarmo, R.; Mace, P.D.; Shirley, S.; Condon, S.M.; Chunduru, S.K.; McKinlay, M.A.; Vaux, D.L.; Silke, J.; et al. Smac mimetics activate the E3 ligase activity of cIAP1 protein by promoting RING domain dimerization. J. Biol. Chem. 2011, 286, 17015-17028. [CrossRef]

54. Phillips, A.H.; Schoeffler, A.J.; Matsui, T.; Weiss, T.M.; Blankenship, J.W.; Zobel, K.; Giannetti, A.M.; Dueber, E.C.; Fairbrother, W.J. Internal motions prime cIAP1 for rapid activation. Nat. Struct. Mol. Biol. 2014, 21, 1068-1074. [CrossRef]

55. Csomos, R.A.; Brady, G.F.; Duckett, C.S. Enhanced cytoprotective effects of the inhibitor of apoptosis protein cellular IAP1 through stabilization with TRAF2. J. Biol. Chem. 2009, 284, 20531-20539. [CrossRef]

56. Vischioni, B.; Giaccone, G.; Span, S.W.; Kruyt, F.A.; Rodriguez, J.A. Nuclear shuttling and TRAF2-mediated retention in the cytoplasm regulate the subcellular localization of cIAP1 and cIAP2. Exp. Cell Res. 2004, 298, 535-548. [CrossRef]

57. Nakatani, Y.; Kleffmann, T.; Linke, K.; Condon, S.M.; Hinds, M.G.; Day, C.L. Regulation of ubiquitin transfer by XIAP, a dimeric RING E3 ligase. Biochem. J. 2013, 450, 629-638. [CrossRef] [PubMed]

58. Dhillon, B.; Aleithan, F.; Abdul-Sater, Z.; Abdul-Sater, A.A. The Evolving Role of TRAFs in Mediating Inflammatory Responses. Front. Immunol. 2019, 10, 104. [CrossRef] [PubMed]

59. Rothe, M.; Pan, M.G.; Henzel, W.J.; Ayres, T.M.; Goeddel, D.V. The TNFR2-TRAF signaling complex contains two novel proteins related to baculoviral inhibitor of apoptosis proteins. Cell 1995, 83, 1243-1252. [CrossRef]

60. Shi, J.H.; Sun, S.C. Tumor Necrosis Factor Receptor-Associated Factor Regulation of Nuclear Factor $\mathrm{\kappa B}$ and Mitogen-Activated Protein Kinase Pathways. Front. Immunol. 2018, 9, 1849. [CrossRef] [PubMed] 
61. Marivin, A.; Berthelet, J.; Cartier, J.; Paul, C.; Gemble, S.; Morizot, A.; Boireau, W.; Saleh, M.; Bertoglio, J.; Solary, E.; et al. cIAP1 regulates TNF-mediated cdc42 activation and filopodia formation. Oncogene 2014, 33, 5534-5545. [CrossRef]

62. Dupoux, A.; Cartier, J.; Cathelin, S.; Filomenko, R.; Solary, E.; Dubrez-Daloz, L. cIAP1-dependent TRAF2 degradation regulates the differentiation of monocytes into macrophages and their response to CD40 ligand. Blood 2009, 113, 175-185. [CrossRef]

63. Vallabhapurapu, S.; Matsuzawa, A.; Zhang, W.; Tseng, P.H.; Keats, J.J.; Wang, H.; Vignali, D.A.; Bergsagel, P.L.; Karin, M. Nonredundant and complementary functions of TRAF2 and TRAF3 in a ubiquitination cascade that activates NIK-dependent alternative NF-kappaB signaling. Nat. Immunol. 2008, 9, 1364-1370. [CrossRef]

64. Wilkinson, J.C.; Wilkinson, A.S.; Galbán, S.; Csomos, R.A.; Duckett, C.S. Apoptosis-inducing factor is a target for ubiquitination through interaction with XIAP. Mol. Cell Biol. 2008, 28, 237-247. [CrossRef]

65. Lewis, E.M.; Wilkinson, A.S.; Davis, N.Y.; Horita, D.A.; Wilkinson, J.C. Nondegradative ubiquitination of apoptosis inducing factor (AIF) by X-linked inhibitor of apoptosis at a residue critical for AIF-mediated chromatin degradation. Biochemistry 2011, 50, 11084-11096. [CrossRef]

66. Bornstein, B.; Edison, N.; Gottfried, Y.; Lev, T.; Shekhtman, A.; Gonen, H.; Rajalingam, K.; Larisch, S. X-linked Inhibitor of Apoptosis Protein promotes the degradation of its antagonist, the pro-apoptotic ARTS protein. Int. J. Biochem. Cell Biol. 2012, 44, 489-495. [CrossRef]

67. Suzuki, Y.; Nakabayashi, Y.; Takahashi, R. Ubiquitin-protein ligase activity of X-linked inhibitor of apoptosis protein promotes proteasomal degradation of caspase-3 and enhances its anti-apoptotic effect in Fas-induced cell death. Proc. Natl. Acad. Sci. USA 2001, 98, 8662-8667. [CrossRef]

68. Choi, Y.E.; Butterworth, M.; Malladi, S.; Duckett, C.S.; Cohen, G.M.; Bratton, S.B. The E3 ubiquitin ligase cIAP1 binds and ubiquitinates caspase- 3 and -7 via unique mechanisms at distinct steps in their processing. J. Biol. Chem. 2009, 284, 12772-12782. [CrossRef]

69. Tenev, T.; Bianchi, K.; Darding, M.; Broemer, M.; Langlais, C.; Wallberg, F.; Zachariou, A.; Lopez, J.; MacFarlane, M.; Cain, K.; et al. The Ripoptosome, a signaling platform that assembles in response to genotoxic stress and loss of IAPs. Mol. Cell 2011, 43, 432-448. [CrossRef]

70. Yang, Y.; Fang, S.; Jensen, J.P.; Weissman, A.M.; Ashwell, J.D. Ubiquitin protein ligase activity of IAPs and their degradation in proteasomes in response to apoptotic stimuli. Science 2000, 288, 874-877. [CrossRef]

71. Darding, M.; Feltham, R.; Tenev, T.; Bianchi, K.; Benetatos, C.; Silke, J.; Meier, P. Molecular determinants of Smac mimetic induced degradation of cIAP1 and cIAP2. Cell Death Differ. 2011, 18, 1376-1386. [CrossRef]

72. Caballero-López, M.J.; Nieto-Díaz, M.; Yunta, M.; Reigada, D.; Muñoz-Galdeano, T.; Del Águila, Á.; Navarro-Ruíz, R.; Pita-Thomas, W.; Lindholm, D.; Maza, R.M. XIAP Interacts with and Regulates the Activity of FAF1. Biochim. Biophys. Acta. Mol. Cell Res. 2017, 1864, 1335-1348. [CrossRef]

73. Hu, S.; Yang, X. Cellular inhibitor of apoptosis 1 and 2 are ubiquitin ligases for the apoptosis inducer Smac/DIABLO. J. Biol. Chem. 2003, 278, 10055-10060. [CrossRef]

74. MacFarlane, M.; Merrison, W.; Bratton, S.B.; Cohen, G.M. Proteasome-mediated degradation of Smac during apoptosis: XIAP promotes Smac ubiquitination in vitro. J. Biol. Chem. 2002, 277, 36611-36616. [CrossRef]

75. Huang, X.; Wang, X.N.; Yuan, X.D.; Wu, W.Y.; Lobie, P.E.; Wu, Z. XIAP facilitates breast and colon carcinoma growth via promotion of $\mathrm{p} 62$ depletion through ubiquitination-dependent proteasomal degradation. Oncogene 2019, 38, 1448-1460. [CrossRef]

76. Brady, G.F.; Galbán, S.; Liu, X.; Basrur, V.; Gitlin, J.D.; Elenitoba-Johnson, K.S.; Wilson, T.E.; Duckett, C.S. Regulation of the copper chaperone CCS by XIAP-mediated ubiquitination. Mol. Cell Biol. 2010, 30, 1923-1936. [CrossRef]

77. Burstein, E.; Ganesh, L.; Dick, R.D.; van De Sluis, B.; Wilkinson, J.C.; Klomp, L.W.; Wijmenga, C.; Brewer, G.J.; Nabel, G.J.; Duckett, C.S. A novel role for XIAP in copper homeostasis through regulation of MURR1. EMBO J. 2004, 23, 244-254. [CrossRef]

78. Murali, A.; Shin, J.; Yurugi, H.; Krishnan, A.; Akutsu, M.; Carpy, A.; Macek, B.; Rajalingam, K. Ubiquitin-dependent regulation of Cdc42 by XIAP. Cell Death Dis. 2017, 8, e2900. [CrossRef]

79. Jeong, D.H.; Choi, Y.N.; Seo, T.W.; Lee, J.S.; Yoo, S.J. Ubiquitin-proteasome dependent regulation of Profilin2 (Pfn2) by a cellular inhibitor of apoptotic protein 1 (cIAP1). Biochem. Biophys. Res. Commun. 2018, 506, 423-428. [CrossRef] 
80. Oberoi, T.K.; Dogan, T.; Hocking, J.C.; Scholz, R.P.; Mooz, J.; Anderson, C.L.; Karreman, C.; Meyer zu Heringdorf, D.; Schmidt, G.; Ruonala, M.; et al. IAPs regulate the plasticity of cell migration by directly targeting Rac1 for degradation. EMBO J. 2012, 31, 14-28. [CrossRef]

81. Seidelin, J.B.; Larsen, S.; Linnemann, D.; Vainer, B.; Coskun, M.; Troelsen, J.T.; Nielsen, O.H. Cellular inhibitor of apoptosis protein 2 controls human colonic epithelial restitution, migration, and Rac1 activation. Am. J. Physiol. Gastrointest. Liver Physiol. 2015, 308, G92-G99. [CrossRef]

82. Hornburger, M.C.; Mayer, B.A.; Leonhardt, S.; Willer, E.A.; Zahler, S.; Beyerle, A.; Rajalingam, K.; Vollmar, A.M.; Furst, R. A novel role for inhibitor of apoptosis (IAP) proteins as regulators of endothelial barrier function by mediating RhoA activation. Faseb J. Publ. Fed. Am. Soc. Exp. Biol. 2014, 28, 1938-1946. [CrossRef]

83. Kim, K.S.; Heo, J.I.; Choi, K.J.; Bae, S. Enhancement of cellular radiation sensitivity through degradation of Chk1 by the XIAP-XAF1 complex. Cancer Biol. 2014, 15, 1622-1634. [CrossRef]

84. Nicholson, J.; Jevons, S.J.; Groselj, B.; Ellermann, S.; Konietzny, R.; Kerr, M.; Kessler, B.M.; Kiltie, A.E. E3 Ligase cIAP2 Mediates Downregulation of MRE11 and Radiosensitization in Response to HDAC Inhibition in Bladder Cancer. Cancer Res. 2017, 77, 3027-3039. [CrossRef]

85. Chen, S.M.; Lin, T.K.; Tseng, Y.Y.; Tu, C.H.; Lui, T.N.; Huang, S.F.; Hsieh, L.L.; Li, Y.Y. Targeting inhibitors of apoptosis proteins suppresses medulloblastoma cell proliferation via G2/M phase arrest and attenuated neddylation of p21. Cancer Med. 2018, 7, 3988-4003. [CrossRef]

86. Arora, V.; Cheung, H.H.; Plenchette, S.; Micali, O.C.; Liston, P.; Korneluk, R.G. Degradation of survivin by the X-linked inhibitor of apoptosis (XIAP)-XAF1 complex. J. Biol. Chem. 2007, 282, 26202-26209. [CrossRef]

87. Labbé, K.; McIntire, C.R.; Doiron, K.; Leblanc, P.M.; Saleh, M. Cellular inhibitors of apoptosis proteins cIAP1 and CIAP2 are required for efficient caspase-1 activation by the inflammasome. Immunity 2011, 35, 897-907. [CrossRef]

88. Hsieh, W.C.; Hsu, T.S.; Chang, Y.J.; Lai, M.Z. IL-6 receptor blockade corrects defects of XIAP-deficient regulatory T cells. Nat. Commun. 2018, 9, 463. [CrossRef]

89. Jin, H.S.; Lee, D.H.; Kim, D.H.; Chung, J.H.; Lee, S.J.; Lee, T.H. cIAP1, cIAP2, and XIAP act cooperatively via nonredundant pathways to regulate genotoxic stress-induced nuclear factor-kappaB activation. Cancer Res. 2009, 69, 1782-1791. [CrossRef]

90. Bertrand, M.J.; Milutinovic, S.; Dickson, K.M.; Ho, W.C.; Boudreault, A.; Durkin, J.; Gillard, J.W.; Jaquith, J.B.; Morris, S.J.; Barker, P.A. cIAP1 and cIAP2 facilitate cancer cell survival by functioning as E3 ligases that promote RIP1 ubiquitination. Mol. Cell 2008, 30, 689-700. [CrossRef]

91. Yang, Y.; Kelly, P.; Shaffer, A.L.; Schmitz, R.; Yoo, H.M.; Liu, X.; Huang, D.W.; Webster, D.; Young, R.M.; Nakagawa, M.; et al. Target. Non-Proteolytic Protein Ubiquitination Treat. Diffus. Large B Cell Lymphoma. Cancer Cell 2016, 29, 494-507. [CrossRef]

92. Takeda, A.N.; Oberoi-Khanuja, T.K.; Glatz, G.; Schulenburg, K.; Scholz, R.P.; Carpy, A.; Macek, B.; Remenyi, A.; Rajalingam, K. Ubiquitin-dependent regulation of MEKK2/3-MEK5-ERK5 signaling module by XIAP and cIAP1. EMBO J. 2014, 33, 1784-1801. [CrossRef] [PubMed]

93. Winsauer, G.; Resch, U.; Hofer-Warbinek, R.; Schichl, Y.M.; de Martin, R. XIAP regulates bi-phasic NF-kappaB induction involving physical interaction and ubiquitination of MEKK2. Cell Signal. 2008, 20, 2107-2112. [CrossRef]

94. Van Themsche, C.; Leblanc, V.; Parent, S.; Asselin, E. X-linked inhibitor of apoptosis protein (XIAP) regulates PTEN ubiquitination, content, and compartmentalization. J. Biol. Chem. 2009, 284, 20462-20466. [CrossRef]

95. Dogan, T.; Harms, G.S.; Hekman, M.; Karreman, C.; Oberoi, T.K.; Alnemri, E.S.; Rapp, U.R.; Rajalingam, K. X-linked and cellular IAPs modulate the stability of C-RAF kinase and cell motility. Nat. Cell Biol. 2008, 10, 1447-1455. [CrossRef]

96. Kaur, S.; Wang, F.; Venkatraman, M.; Arsura, M. X-linked inhibitor of apoptosis (XIAP) inhibits c-Jun N-terminal kinase 1 (JNK1) activation by transforming growth factor beta1 (TGF-beta1) through ubiquitin-mediated proteosomal degradation of the TGF-beta1-activated kinase 1 (TAK1). J. Biol. Chem. 2005, 280, 38599-38608. [CrossRef]

97. Neil, J.R.; Tian, M.; Schiemann, W.P. X-linked inhibitor of apoptosis protein and its E3 ligase activity promote transforming growth factor-\{beta\}-mediated nuclear factor-\{kappa\}B activation during breast cancer progression. J. Biol. Chem. 2009, 284, 21209-21217. [CrossRef] 
98. Samuel, T.; Welsh, K.; Lober, T.; Togo, S.H.; Zapata, J.M.; Reed, J.C. Distinct BIR domains of cIAP1 mediate binding to and ubiquitination of tumor necrosis factor receptor-associated factor 2 and second mitochondrial activator of caspases. J. Biol. Chem. 2006, 281, 1080-1090. [CrossRef]

99. Li, X.; Yang, Y.; Ashwell, J.D. TNF-RII and c-IAP1 mediate ubiquitination and degradation of TRAF2. Nature 2002, 416, 345-347. [CrossRef]

100. Matsuzawa, A.; Tseng, P.H.; Vallabhapurapu, S.; Luo, J.L.; Zhang, W.; Wang, H.; Vignali, D.A.; Gallagher, E.; Karin, M. Essential cytoplasmic translocation of a cytokine receptor-assembled signaling complex. Science 2008, 321, 663-668. [CrossRef]

101. Tseng, P.H.; Matsuzawa, A.; Zhang, W.; Mino, T.; Vignali, D.A.; Karin, M. Different modes of ubiquitination of the adaptor TRAF3 selectively activate the expression of type I interferons and proinflammatory cytokines. Nat. Immunol. 2010, 11, 70-75. [CrossRef] [PubMed]

102. Mao, A.P.; Li, S.; Zhong, B.; Li, Y.; Yan, J.; Li, Q.; Teng, C.; Shu, H.B. Virus-triggered ubiquitination of TRAF3/6 by cIAP1/2 is essential for induction of interferon-beta (IFN-beta) and cellular antiviral response. J. Biol. Chem. 2010, 285, 9470-9476. [CrossRef] [PubMed]

103. Qi, Y.; Xia, P. Cellular inhibitor of apoptosis protein-1 (cIAP1) plays a critical role in beta-cell survival under endoplasmic reticulum stress: Promoting ubiquitination and degradation of C/EBP homologous protein (CHOP). J. Biol. Chem. 2012, 287, 32236-32245. [CrossRef]

104. Allègre, J.; Cartier, J.; Glorian, V.; Droin, N.; Dumetier, B.; Kayaci, C.; Berthelet, J.; Gemble, S.; Vuillier, C.; Maillet, L.; et al. E2F1 binds to the peptide-binding groove within the BIR3 domain of cIAP1 and requires cIAP1 for chromatin binding. PLoS ONE 2018, 13, e0206253. [CrossRef]

105. Glorian, V.; Allègre, J.; Berthelet, J.; Dumetier, B.; Boutanquoi, P.M.; Droin, N.; Kayaci, C.; Cartier, J.; Gemble, S.; Marcion, G.; et al. DNA damage and S phase-dependent E2F1 stabilization requires the cIAP1 E3-ubiquitin ligase and is associated with K63-poly-ubiquitination on lysine 161/164 residues. Cell Death Dis. 2017, 8, e2816. [CrossRef]

106. Park, C.V.; Ivanova, I.G.; Kenneth, N.S. XIAP upregulates expression of HIF target genes by targeting HIF1 $\alpha$ for Lys63-linked polyubiquitination. Nucleic Acids Res. 2017, 45, 9336-9347. [CrossRef]

107. Wang, T.; Wang, J. K63-linked polyubiquitination of IRF1: An essential step in the IL-1 signaling cascade. Cell Mol. Immunol. 2014, 11, 407-409. [CrossRef]

108. Xu, L.; Zhu, J.; Hu, X.; Zhu, H.; Kim, H.T.; LaBaer, J.; Goldberg, A.; Yuan, J. c-IAP1 cooperates with Myc by acting as a ubiquitin ligase for Mad1. Mol. Cell 2007, 28, 914-922. [CrossRef]

109. Wang, S.L.; Hawkins, C.J.; Yoo, S.J.; Muller, H.A.; Hay, B.A. The Drosophila caspase inhibitor DIAP1 is essential for cell survival and is negatively regulated by HID. Cell 1999, 98, 453-463. [CrossRef]

110. Igaki, T.; Yamamoto-Goto, Y.; Tokushige, N.; Kanda, H.; Miura, M. Down-regulation of DIAP1 triggers a novel Drosophila cell death pathway mediated by Dark and DRONC. J. Biol. Chem. 2002, 277, 23103-23106. [CrossRef]

111. Chai, J.; Yan, N.; Huh, J.R.; Wu, J.W.; Li, W.; Hay, B.A.; Shi, Y. Molecular mechanism of Reaper-Grim-Hid-mediated suppression of DIAP1-dependent Dronc ubiquitination. Nat. Struct. Biol. 2003, 10, 892-898. [CrossRef]

112. Wilson, R.; Goyal, L.; Ditzel, M.; Zachariou, A.; Baker, D.A.; Agapite, J.; Steller, H.; Meier, P. The DIAP1 RING finger mediates ubiquitination of Dronc and is indispensable for regulating apoptosis. Nat. Cell Biol. 2002, 4, 445-450. [CrossRef]

113. Eckelman, B.P.; Salvesen, G.S. The human anti-apoptotic proteins cIAP1 and cIAP2 bind but do not inhibit caspases. J. Biol. Chem. 2006, 281, 3254-3260. [CrossRef]

114. Scott, F.L.; Denault, J.B.; Riedl, S.J.; Shin, H.; Renatus, M.; Salvesen, G.S. XIAP inhibits caspase-3 and -7 using two binding sites: Evolutionarily conserved mechanism of IAPs. EMBO J. 2005, 24, 645-655. [CrossRef]

115. Takahashi, R.; Deveraux, Q.; Tamm, I.; Welsh, K.; Assa-Munt, N.; Salvesen, G.S.; Reed, J.C. A single BIR domain of XIAP sufficient for inhibiting caspases. J. Biol. Chem. 1998, 273, 7787-7790. [CrossRef]

116. Chai, J.; Shiozaki, E.; Srinivasula, S.M.; Wu, Q.; Datta, P.; Alnemri, E.S.; Shi, Y. Structural basis of caspase-7 inhibition by XIAP. Cell 2001, 104, 769-780. [CrossRef]

117. Riedl, S.J.; Renatus, M.; Schwarzenbacher, R.; Zhou, Q.; Sun, C.; Fesik, S.W.; Liddington, R.C.; Salvesen, G.S. Structural basis for the inhibition of caspase-3 by XIAP. Cell 2001, 104, 791-800. [CrossRef]

118. Schile, A.J.; Garcia-Fernandez, M.; Steller, H. Regulation of apoptosis by XIAP ubiquitin-ligase activity. Genes Dev. 2008, 22, 2256-2266. [CrossRef] 
119. Suzuki, Y.; Nakabayashi, Y.; Nakata, K.; Reed, J.C.; Takahashi, R. X-linked inhibitor of apoptosis protein (XIAP) inhibits caspase-3 and -7 in distinct modes. J. Biol. Chem. 2001, 276, 27058-27063. [CrossRef]

120. Arnt, C.R.; Chiorean, M.V.; Heldebrant, M.P.; Gores, G.J.; Kaufmann, S.H. Synthetic Smac/DIABLO peptides enhance the effects of chemotherapeutic agents by binding XIAP and cIAP1 in situ. J. Biol. Chem. 2002, 277, 44236-44243. [CrossRef]

121. Wu, G.; Chai, J.; Suber, T.L.; Wu, J.W.; Du, C.; Wang, X.; Shi, Y. Structural basis of IAP recognition by Smac/DIABLO. Nature 2000, 408, 1008-1012. [CrossRef]

122. Liu, Z.; Sun, C.; Olejniczak, E.T.; Meadows, R.P.; Betz, S.F.; Oost, T.; Herrmann, J.; Wu, J.C.; Fesik, S.W. Structural basis for binding of Smac/DIABLO to the XIAP BIR3 domain. Nature 2000, 408, 1004-1008. [CrossRef]

123. Ekert, P.G.; Silke, J.; Hawkins, C.J.; Verhagen, A.M.; Vaux, D.L. DIABLO promotes apoptosis by removing MIHA/XIAP from processed caspase 9. J. Cell Biol. 2001, 152, 483-490. [CrossRef]

124. Huang, Y.; Rich, R.L.; Myszka, D.G.; Wu, H. Requirement of both the second and third BIR domains for the relief of X-linked inhibitor of apoptosis protein (XIAP)-mediated caspase inhibition by Smac. J. Biol. Chem. 2003, 278, 49517-49522. [CrossRef]

125. Hui, K.K.; Kanungo, A.K.; Elia, A.J.; Henderson, J.T. Caspase-3 deficiency reveals a physiologic role for Smac/DIABLO in regulating programmed cell death. Cell Death Differ. 2011, 18, 1780-1790. [CrossRef]

126. Yang, Q.H.; Du, C. Smac/DIABLO selectively reduces the levels of c-IAP1 and c-IAP2 but not that of XIAP and livin in HeLa cells. J. Biol. Chem. 2004, 279, 16963-16970. [CrossRef]

127. Qiu, W.; Liu, H.; Sebastini, A.; Sun, Q.; Wang, H.; Zhang, L.; Yu, J. An apoptosis-independent role of SMAC in tumor suppression. Oncogene 2013, 32, 2380-2389. [CrossRef]

128. Ma, L.; Huang, Y.; Song, Z.; Feng, S.; Tian, X.; Du, W.; Qiu, X.; Heese, K.; Wu, M. Livin promotes Smac/DIABLO degradation by ubiquitin-proteasome pathway. Cell Death Differ. 2006, 13, 2079-2088. [CrossRef]

129. Hamacher-Brady, A.; Choe, S.C.; Krijnse-Locker, J.; Brady, N.R. Intramitochondrial recruitment of endolysosomes mediates Smac degradation and constitutes a novel intrinsic apoptosis antagonizing function of XIAP E3 ligase. Cell Death Differ. 2014, 21, 1862-1876. [CrossRef]

130. Xia, L.; Tan, S.; Zhou, Y.; Lin, J.; Wang, H.; Oyang, L.; Tian, Y.; Liu, L.; Su, M.; Cao, D.; et al. Role of the Nfkb-signaling pathway in cancer. OncoTargets Ther. 2018, 11, 2063-2073. [CrossRef]

131. Mukhopadhyay, H.; Lee, N.Y. Multifaceted roles of TAK1 signaling in cancer. Oncogene 2019. [CrossRef]

132. Yamaguchi, K.; Nagai, S.; Ninomiya-Tsuji, J.; Nishita, M.; Tamai, K.; Irie, K.; Ueno, N.; Nishida, E.; Shibuya, H.; Matsumoto, K. XIAP, a cellular member of the inhibitor of apoptosis protein family, links the receptors to TAB1-TAK1 in the BMP signaling pathway. EMBO J. 1999, 18, 179-187. [CrossRef]

133. Birkey Reffey, S.; Wurthner, J.U.; Parks, W.T.; Roberts, A.B.; Duckett, C.S. X-linked inhibitor of apoptosis protein functions as a cofactor in transforming growth factor-beta signaling. J. Biol. Chem. 2001, 276, 26542-26549. [CrossRef]

134. Van Themsche, C.; Chaudhry, P.; Leblanc, V.; Parent, S.; Asselin, E. XIAP gene expression and function is regulated by autocrine and paracrine TGF-beta signaling. Mol. Cancer 2010, 9, 216. [CrossRef]

135. Biswas, S.; Shisler, J.L. Molluscum Contagiosum Virus MC159 Abrogates cIAP1-NEMO Interactions and Inhibits NEMO Polyubiquitination. J. Virol 2017, 91. [CrossRef]

136. Yin, M.; Wang, X.; Lu, J. Advances in IKBKE as a potential target for cancer therapy. Cancer Med. 2020, 9, 247-258. [CrossRef]

137. Varfolomeev, E.; Blankenship, J.W.; Wayson, S.M.; Fedorova, A.V.; Kayagaki, N.; Garg, P.; Zobel, K.; Dynek, J.N.; Elliott, L.O.; Wallweber, H.J.; et al. IAP antagonists induce autoubiquitination of c-IAPs, NF-kappaB activation, and TNFalpha-dependent apoptosis. Cell 2007, 131, 669-681. [CrossRef]

138. Vince, J.E.; Wong, W.W.; Khan, N.; Feltham, R.; Chau, D.; Ahmed, A.U.; Benetatos, C.A.; Chunduru, S.K.; Condon, S.M.; McKinlay, M.; et al. IAP Antagonists Target cIAP1 to Induce TNFalpha-Dependent Apoptosis. Cell 2007, 131, 682-693. [CrossRef]

139. Annunziata, C.M.; Davis, R.E.; Demchenko, Y.; Bellamy, W.; Gabrea, A.; Zhan, F.; Lenz, G.; Hanamura, I.; Wright, G.; Xiao, W.; et al. Frequent engagement of the classical and alternative NF-kappaB pathways by diverse genetic abnormalities in multiple myeloma. Cancer Cell 2007, 12, 115-130. [CrossRef]

140. Keats, J.J.; Fonseca, R.; Chesi, M.; Schop, R.; Baker, A.; Chng, W.J.; Van Wier, S.; Tiedemann, R.; Shi, C.X.; Sebag, M.; et al. Promiscuous mutations activate the noncanonical NF-kappaB pathway in multiple myeloma. Cancer Cell 2007, 12, 131-144. [CrossRef] 
141. Zarnegar, B.J.; Wang, Y.; Mahoney, D.J.; Dempsey, P.W.; Cheung, H.H.; He, J.; Shiba, T.; Yang, X.; Yeh, W.C.; Mak, T.W.; et al. Noncanonical NF-kappaB activation requires coordinated assembly of a regulatory complex of the adaptors cIAP1, cIAP2, TRAF2 and TRAF3 and the kinase NIK. Nat. Immunol. 2008, 9, 1371-1378. [CrossRef] [PubMed]

142. He, S.; Wang, X. RIP kinases as modulators of inflammation and immunity. Nat. Immunol. 2018, 19, $912-922$. [CrossRef]

143. Hasegawa, M.; Fujimoto, Y.; Lucas, P.C.; Nakano, H.; Fukase, K.; Núñez, G.; Inohara, N. A critical role of RICK/RIP2 polyubiquitination in Nod-induced NF-kappaB activation. EMBO J. 2008, 27, 373-383. [CrossRef] [PubMed]

144. Ea, C.K.; Deng, L.; Xia, Z.P.; Pineda, G.; Chen, Z.J. Activation of IKK by TNFalpha requires site-specific ubiquitination of RIP1 and polyubiquitin binding by NEMO. Mol. Cell 2006, 22, 245-257. [CrossRef]

145. O'Donnell, M.A.; Legarda-Addison, D.; Skountzos, P.; Yeh, W.C.; Ting, A.T. Ubiquitination of RIP1 regulates an NF-kappaB-independent cell-death switch in TNF signaling. Curr. Biol. 2007, 17, 418-424. [CrossRef]

146. Cusson-Hermance, N.; Khurana, S.; Lee, T.H.; Fitzgerald, K.A.; Kelliher, M.A. Rip1 mediates the Trif-dependent toll-like receptor 3- and 4-induced NF-\{kappa\}B activation but does not contribute to interferon regulatory factor 3 activation. J. Biol. Chem. 2005, 280, 36560-36566. [CrossRef]

147. Annibaldi, A.; Meier, P. Checkpoints in TNF-Induced Cell Death: Implications in Inflammation and Cancer. Trends Mol. Med. 2018, 24, 49-65. [CrossRef]

148. Emmerich, C.H.; Bakshi, S.; Kelsall, I.R.; Ortiz-Guerrero, J.; Shpiro, N.; Cohen, P. Lys63/Met1-hybrid ubiquitin chains are commonly formed during the activation of innate immune signalling. Biochem. Biophys. Res. Commun. 2016, 474, 452-461. [CrossRef]

149. Varfolomeev, E.; Goncharov, T.; Fedorova, A.V.; Dynek, J.N.; Zobel, K.; Deshayes, K.; Fairbrother, W.J.; Vucic, D. c-IAP1 and c-IAP2 are critical mediators of tumor necrosis factor alpha (TNFalpha)-induced NF-kappaB activation. J. Biol. Chem. 2008, 283, 24295-24299. [CrossRef]

150. Park, S.M.; Yoon, J.B.; Lee, T.H. Receptor interacting protein is ubiquitinated by cellular inhibitor of apoptosis proteins (c-IAP1 and c-IAP2) in vitro. Febs Lett. 2004, 566, 151-156. [CrossRef]

151. Rosebeck, S.; Rehman, A.O.; Apel, I.J.; Kohrt, D.; Appert, A.; O’Donnell, M.A.; Ting, A.T.; Du, M.Q.; Baens, M.; Lucas, P.C.; et al. The API2-MALT1 fusion exploits TNFR pathway-associated RIP1 ubiquitination to promote oncogenic NF-kB signaling. Oncogene 2014, 33, 2520-2530. [CrossRef]

152. de Almagro, M.C.; Goncharov, T.; Newton, K.; Vucic, D. Cellular IAP proteins and LUBAC differentially regulate necrosome-associated RIP1 ubiquitination. Cell Death Dis. 2015, 6, e1800. [CrossRef] [PubMed]

153. Borghi, A.; Haegman, M.; Fischer, R.; Carpentier, I.; Bertrand, M.J.M.; Libert, C.; Afonina, I.S.; Beyaert, R. The E3 ubiquitin ligases HOIP and cIAP1 are recruited to the TNFR2 signaling complex and mediate TNFR2-induced canonical NF-кB signaling. Biochem. Pharm. 2018, 153, 292-298. [CrossRef] [PubMed]

154. Moulin, M.; Anderton, H.; Voss, A.K.; Thomas, T.; Wong, W.W.; Bankovacki, A.; Feltham, R.; Chau, D.; Cook, W.D.; Silke, J.; et al. IAPs limit activation of RIP kinases by TNF receptor 1 during development. EMBO J. 2012, 31, 1679-1691. [CrossRef]

155. Li, L.; Thomas, R.M.; Suzuki, H.; De Brabander, J.K.; Wang, X.; Harran, P.G. A small molecule Smac mimic potentiates TRAIL- and TNFalpha-mediated cell death. Science 2004, 305, 1471-1474. [CrossRef]

156. Petersen, S.L.; Wang, L.; Yalcin-Chin, A.; Li, L.; Peyton, M.; Minna, J.; Harran, P.; Wang, X. Autocrine TNFalpha signaling renders human cancer cells susceptible to Smac-mimetic-induced apoptosis. Cancer Cell 2007, 12, 445-456. [CrossRef]

157. Geserick, P.; Hupe, M.; Moulin, M.; Wong, W.W.; Feoktistova, M.; Kellert, B.; Gollnick, H.; Silke, J.; Leverkus, M. Cellular IAPs inhibit a cryptic CD95-induced cell death by limiting RIP1 kinase recruitment. J. Cell Biol. 2009, 187, 1037-1054. [CrossRef]

158. Vanlangenakker, N.; Vanden Berghe, T.; Bogaert, P.; Laukens, B.; Zobel, K.; Deshayes, K.; Vucic, D.; Fulda, S.; Vandenabeele, P.; Bertrand, M.J. cIAP1 and TAK1 protect cells from TNF-induced necrosis by preventing RIP1/RIP3-dependent reactive oxygen species production. Cell Death Differ. 2011, 18, 656-665. [CrossRef]

159. Feoktistova, M.; Geserick, P.; Kellert, B.; Dimitrova, D.P.; Langlais, C.; Hupe, M.; Cain, K.; MacFarlane, M.; Hacker, G.; Leverkus, M. cIAPs block Ripoptosome formation, a RIP1/caspase-8 containing intracellular cell death complex differentially regulated by cFLIP isoforms. Mol. Cell 2011, 43, 449-463. [CrossRef] 
160. Estornes, Y.; Aguileta, M.A.; Dubuisson, C.; De Keyser, J.; Goossens, V.; Kersse, K.; Samali, A.; Vandenabeele, P.; Bertrand, M.J. RIPK1 promotes death receptor-independent caspase-8-mediated apoptosis under unresolved ER stress conditions. Cell Death Dis. 2014, 5, e1555. [CrossRef]

161. McComb, S.; Cheung, H.H.; Korneluk, R.G.; Wang, S.; Krishnan, L.; Sad, S. cIAP1 and cIAP2 limit macrophage necroptosis by inhibiting Rip1 and Rip3 activation. Cell Death Differ. 2012, 19, 1791-1801. [CrossRef]

162. Kaiser, W.J.; Sridharan, H.; Huang, C.; Mandal, P.; Upton, J.W.; Gough, P.J.; Sehon, C.A.; Marquis, R.W.; Bertin, J.; Mocarski, E.S. Toll-like receptor 3-mediated necrosis via TRIF, RIP3, and MLKL. J. Biol. Chem. 2013, 288, 31268-31279. [CrossRef] [PubMed]

163. Vince, J.E.; Wong, W.W.; Gentle, I.; Lawlor, K.E.; Allam, R.; O’Reilly, L.; Mason, K.; Gross, O.; Ma, S.; Guarda, G.; et al. Inhibitor of apoptosis proteins limit RIP3 kinase-dependent interleukin-1 activation. Immunity 2012, 36, 215-227. [CrossRef] [PubMed]

164. Vanlangenakker, N.; Bertrand, M.J.; Bogaert, P.; Vandenabeele, P.; Vanden Berghe, T. TNF-induced necroptosis in L929 cells is tightly regulated by multiple TNFR1 complex I and II members. Cell Death Dis. 2011, 2, e230. [CrossRef]

165. Newton, K.; Dugger, D.L.; Wickliffe, K.E.; Kapoor, N.; de Almagro, M.C.; Vucic, D.; Komuves, L.; Ferrando, R.E.; French, D.M.; Webster, J.; et al. Activity of protein kinase RIPK3 determines whether cells die by necroptosis or apoptosis. Science 2014, 343, 1357-1360. [CrossRef]

166. Lawlor, K.E.; Khan, N.; Mildenhall, A.; Gerlic, M.; Croker, B.A.; D'Cruz, A.A.; Hall, C.; Kaur Spall, S.; Anderton, H.; Masters, S.L.; et al. RIPK3 promotes cell death and NLRP3 inflammasome activation in the absence of MLKL. Nat. Commun. 2015, 6, 6282. [CrossRef]

167. Lawlor, K.E.; Feltham, R.; Yabal, M.; Conos, S.A.; Chen, K.W.; Ziehe, S.; Graß, C.; Zhan, Y.; Nguyen, T.A.; Hall, C.; et al. XIAP Loss Triggers RIPK3- and Caspase-8-Driven IL-1 $\beta$ Activation and Cell Death as a Consequence of TLR-MyD88-Induced cIAP1-TRAF2 Degradation. Cell Rep. 2017, 20, 668-682. [CrossRef]

168. Yabal, M.; Müller, N.; Adler, H.; Knies, N.; Groß, C.J.; Damgaard, R.B.; Kanegane, H.; Ringelhan, M.; Kaufmann, T.; Heikenwälder, M.; et al. XIAP restricts TNF- and RIP3-dependent cell death and inflammasome activation. Cell Rep. 2014, 7, 1796-1808. [CrossRef]

169. Damgaard, R.B.; Nachbur, U.; Yabal, M.; Wong, W.W.; Fiil, B.K.; Kastirr, M.; Rieser, E.; Rickard, J.A.; Bankovacki, A.; Peschel, C.; et al. The ubiquitin ligase XIAP recruits LUBAC for NOD2 signaling in inflammation and innate immunity. Mol. Cell 2012, 46, 746-758. [CrossRef]

170. Hrdinka, M.; Fiil, B.K.; Zucca, M.; Leske, D.; Bagola, K.; Yabal, M.; Elliott, P.R.; Damgaard, R.B.; Komander, D.; Jost, P.J.; et al. CYLD Limits Lys63- and Met1-Linked Ubiquitin at Receptor Complexes to Regulate Innate Immune Signaling. Cell Rep. 2016, 14, 2846-2858. [CrossRef]

171. Stafford, C.A.; Lawlor, K.E.; Heim, V.J.; Bankovacki, A.; Bernardini, J.P.; Silke, J.; Nachbur, U. IAPs Regulate Distinct Innate Immune Pathways to Co-ordinate the Response to Bacterial Peptidoglycans. Cell Rep. 2018, 22, 1496-1508. [CrossRef]

172. Damgaard, R.B.; Fiil, B.K.; Speckmann, C.; Yabal, M.; zur Stadt, U.; Bekker-Jensen, S.; Jost, P.J.; Ehl, S.; Mailand, N.; Gyrd-Hansen, M. Disease-causing mutations in the XIAP BIR2 domain impair NOD2-dependent immune signalling. EMBO Mol. Med. 2013, 5, 1278-1295. [CrossRef]

173. Krieg, A.; Correa, R.G.; Garrison, J.B.; Le Negrate, G.; Welsh, K.; Huang, Z.; Knoefel, W.T.; Reed, J.C. XIAP mediates NOD signaling via interaction with RIP2. Proc. Natl. Acad. Sci. USA 2009, 106, 14524-14529. [CrossRef]

174. Bauler, L.D.; Duckett, C.S.; O'Riordan, M.X. XIAP regulates cytosol-specific innate immunity to Listeria infection. PLoS Pathog. 2008, 4, e1000142. [CrossRef]

175. Goncharov, T.; Hedayati, S.; Mulvihill, M.M.; Izrael-Tomasevic, A.; Zobel, K.; Jeet, S.; Fedorova, A.V.; Eidenschenk, C.; deVoss, J.; Yu, K.; et al. Disruption of XIAP-RIP2 Association Blocks NOD2-Mediated Inflammatory Signaling. Mol. Cell 2018, 69, 551-565.e557. [CrossRef]

176. Ellwanger, K.; Briese, S.; Arnold, C.; Kienes, I.; Heim, V.; Nachbur, U.; Kufer, T.A. XIAP controls RIPK2 signaling by preventing its deposition in speck-like structures. Life Sci. Alliance 2019, 2. [CrossRef]

177. Gardam, S.; Turner, V.M.; Anderton, H.; Limaye, S.; Basten, A.; Koentgen, F.; Vaux, D.L.; Silke, J.; Brink, R. Deletion of cIAP1 and cIAP2 in murine B lymphocytes constitutively activates cell survival pathways and inactivates the germinal center response. Blood 2011, 117, 4041-4051. [CrossRef] 
178. Varfolomeev, E.; Goncharov, T.; Maecker, H.; Zobel, K.; Komuves, L.G.; Deshayes, K.; Vucic, D. Cellular inhibitors of apoptosis are global regulators of NF-kappaB and MAPK activation by members of the TNF family of receptors. Sci. Signal. 2012, 5, ra22. [CrossRef]

179. Wu, C.J.; Conze, D.B.; Li, X.; Ying, S.X.; Hanover, J.A.; Ashwell, J.D. TNF-alpha induced c-IAP1/TRAF2 complex translocation to a Ubc6-containing compartment and TRAF2 ubiquitination. EMBO J. 2005, 24, 1886-1898. [CrossRef]

180. Vince, J.E.; Chau, D.; Callus, B.; Wong, W.W.; Hawkins, C.J.; Schneider, P.; McKinlay, M.; Benetatos, C.A.; Condon, S.M.; Chunduru, S.K.; et al. TWEAK-FN14 signaling induces lysosomal degradation of a cIAP1-TRAF2 complex to sensitize tumor cells to TNFalpha. J. Cell Biol. 2008, 182, 171-184. [CrossRef]

181. Cabal-Hierro, L.; Rodríguez, M.; Artime, N.; Iglesias, J.; Ugarte, L.; Prado, M.A.; Lazo, P.S. TRAF-mediated modulation of NF-kB AND JNK activation by TNFR2. Cell Signal. 2014, 26, 2658-2666. [CrossRef]

182. Borghi, A.; Verstrepen, L.; Beyaert, R. TRAF2 multitasking in TNF receptor-induced signaling to NF- $k B$, MAP kinases and cell death. Biochem Pharm. 2016, 116, 1-10. [CrossRef]

183. Feltham, R.; Moulin, M.; Vince, J.E.; Mace, P.D.; Wong, W.W.; Anderton, H.; Day, C.L.; Vaux, D.L.; Silke, J. Tumor necrosis factor (TNF) signaling, but not TWEAK (TNF-like weak inducer of apoptosis)-triggered cIAP1 (cellular inhibitor of apoptosis protein 1) degradation, requires cIAP1 RING dimerization and E2 binding. J. Biol. Chem. 2010, 285, 17525-17536. [CrossRef]

184. Xiao, Y.; Jin, J.; Chang, M.; Chang, J.H.; Hu, H.; Zhou, X.; Brittain, G.C.; Stansberg, C.; Torkildsen, Ø.; Wang, X.; et al. Peli1 promotes microglia-mediated CNS inflammation by regulating Traf3 degradation. Nat. Med. 2013, 19, 595-602. [CrossRef]

185. Busca, A.; Konarski, Y.; Gajanayaka, N.; O’Hara, S.; Angel, J.; Kozlowski, M.; Kumar, A. cIAP1/2-TRAF2-SHP-1-Src-MyD88 Complex Regulates Lipopolysaccharide-Induced IL-27 Production through NF-kB Activation in Human Macrophages. J. Immunol. 2018, 200, 1593-1606. [CrossRef]

186. Wen, A.Y.; Sakamoto, K.M.; Miller, L.S. The role of the transcription factor CREB in immune function. J. Immunol. 2010, 185, 6413-6419. [CrossRef]

187. Harikumar, K.B.; Yester, J.W.; Surace, M.J.; Oyeniran, C.; Price, M.M.; Huang, W.C.; Hait, N.C.; Allegood, J.C.; Yamada, A.; Kong, X.; et al. K63-linked polyubiquitination of transcription factor IRF1 is essential for IL-1-induced production of chemokines CXCL10 and CCL5. Nat. Immunol. 2014, 15, 231-238. [CrossRef]

188. Dubrez, L. Regulation of E2F1 Transcription Factor by Ubiquitin Conjugation. Intj. Mol. Sci. $2017,18$. [CrossRef]

189. Cartier, J.; Berthelet, J.; Marivin, A.; Gemble, S.; Edmond, V.; Plenchette, S.; Lagrange, B.; Hammann, A.; Dupoux, A.; Delva, L.; et al. Cellular Inhibitor of Apoptosis Protein-1 (cIAP1) Can Regulate E2F1 Transcription Factor-mediated Control of Cyclin Transcription. J. Biol. Chem. 2011, 286, 26406-26417. [CrossRef]

190. Cao, Z.; Li, X.; Li, J.; Luo, W.; Huang, C.; Chen, J. X-linked inhibitor of apoptosis protein (XIAP) lacking RING domain localizes to the nuclear and promotes cancer cell anchorage-independent growth by targeting the E2F1/Cyclin E axis. Oncotarget. 2014, 5, 7126-7137. [CrossRef]

191. Geisbrecht, E.R.; Montell, D.J. A role for Drosophila IAP1-mediated caspase inhibition in Rac-dependent cell migration. Cell 2004, 118, 111-125. [CrossRef]

192. Rajalingam, K.; Sharma, M.; Paland, N.; Hurwitz, R.; Thieck, O.; Oswald, M.; Machuy, N.; Rudel, T. IAP-IAP complexes required for apoptosis resistance of C. trachomatis-infected cells. PLoS Pathog. 2006, 2, e114. [CrossRef]

193. Lee, S.; Lee, J.Y.; Lee, E.W.; Park, S.; Kang, D.H.; Min, C.; Lee, D.J.; Kang, D.; Song, J.; Kwon, J.; et al. Absence of Cytosolic 2-Cys Prx Subtypes I and II Exacerbates TNF- $\alpha$-Induced Apoptosis via Different Routes. Cell Rep. 2019, 26, 2194-2211.e2196. [CrossRef]

194. Romagny, S.; Bouaouiche, S.; Lucchi, G.; Ducoroy, P.; Bertoldo, J.B.; Terenzi, H.; Bettaieb, A.; Plenchette, S. S-Nitrosylation of cIAP1 Switches Cancer Cell Fate from TNF $\alpha /$ TNFR1-Mediated Cell Survival to Cell Death. Cancer Res. 2018, 78, 1948-1957. [CrossRef]

195. Kato, K.; Tanaka, T.; Sadik, G.; Baba, M.; Maruyama, D.; Yanagida, K.; Kodama, T.; Morihara, T.; Tagami, S.; Okochi, M.; et al. Protein kinase C stabilizes X-linked inhibitor of apoptosis protein (XIAP) through phosphorylation at Ser(87) to suppress apoptotic cell death. Psychogeriatrics 2011, 11, 90-97. [CrossRef]

196. Hou, Y.; Allan, L.A.; Clarke, P.R. Phosphorylation of XIAP by CDK1-cyclin-B1 controls mitotic cell death. J. Cell Sci. 2017, 130, 502-511. [CrossRef] 
197. Plenchette, S.; Cathelin, S.; Rebe, C.; Launay, S.; Ladoire, S.; Sordet, O.; Ponnelle, T.; Debili, N.; Phan, T.H.; Padua, R.A.; et al. Translocation of the inhibitor of apoptosis protein c-IAP1 from the nucleus to the Golgi in hematopoietic cells undergoing differentiation: A nuclear export signal-mediated event. Blood 2004, 104, 2035-2043. [CrossRef]

198. Didelot, C.; Lanneau, D.; Brunet, M.; Bouchot, A.; Cartier, J.; Jacquel, A.; Ducoroy, P.; Cathelin, S.; Decologne, N.; Chiosis, G.; et al. Interaction of heat-shock protein 90 beta isoform (HSP90 beta) with cellular inhibitor of apoptosis 1 (c-IAP1) is required for cell differentiation. Cell Death Differ. 2008, 15, 859-866. [CrossRef]

199. Che, X.; Yang, D.; Zong, H.; Wang, J.; Li, X.; Chen, F.; Chen, X.; Song, X. Nuclear cIAP1 overexpression is a tumor stage- and grade-independent predictor of poor prognosis in human bladder cancer patients. Urol. Oncol. 2012, 30, 450-456. [CrossRef]

200. Hrdinka, M.; Yabal, M. Inhibitor of apoptosis proteins in human health and disease. Genes Immun. 2019, 20, 641-650. [CrossRef]

(C) 2020 by the authors. Licensee MDPI, Basel, Switzerland. This article is an open access article distributed under the terms and conditions of the Creative Commons Attribution (CC BY) license (http://creativecommons.org/licenses/by/4.0/). 